\title{
A study of the river basins and limnology of five humic lakes on Chiloé Island
}

\author{
Estudio de la cuenca y limnología en cinco lagos húmicos de la Isla Chiloé \\ L. VILLALOBOS ${ }^{1 *}$, O. PARRA ${ }^{2}$, M. GRANDJEAN ${ }^{1}$, E. JAQUE $^{3}$, S. WOELFL ${ }^{1} \&$ H. CAMPOS $^{1}(\dagger)$ \\ ${ }^{1}$ Instituto de Zoología, Universidad Austral de Chile, Casilla 567, Valdivia, Chile; \\ *(Corresponding autor) e-mail: 1villalo@uach.cl \\ ${ }^{2}$ Centro EULA, Universidad de Concepción, Concepción, Chile \\ ${ }^{3}$ Departamento de Geografía, Universidad de Concepción, Concepción, Chile
}

\begin{abstract}
From November 1996 to October 1997, the river basins of five humic lakes on Chiloé Island were studied monthly: Lakes Natri, Tepuhueico, Tarahuín, Huillinco and Cucao. The objective of this study was to know the catchment area, river basin and the main physical, chemical and biological characteristics of these humic lakes. The trophic status, the actual loading, and the mass balances of phosphorus and nitrogen were determined in relation to anthropogenic activities. Lakes Cucao and Huillinco were characterized by a marine influence. All the lakes had brown coloured waters, caused by humic substances, which limit their transparency. Lake Natri was the deepest $(58 \mathrm{~m})$, whereas Lake Tepuhueico had the shallowest depth $(25 \mathrm{~m})$. Total phosphorus and nitrogen fluctuated between 23.5 and $35 \mu \mathrm{g} \mathrm{L}^{-1}$ and 197 and $380 \mu \mathrm{g} \mathrm{L}^{-1}$ (annual average) in lakes Natri, Tepuhueico and Tarahuín, respectively. Lakes Cucao and Huillinco showed extremely high concentrations of total nitrogen (annual average $=>3,000 \mu \mathrm{g} \mathrm{L}^{-1}$ ) and total phosphorus $\left(=223\right.$ and $497 \mu \mathrm{g} \mathrm{L}^{-1}$ ), and were classified as hyper-eutrophic. Lake Tarahuín registered the greatest diversity of phytoplankton, with 55 species, including Ceratium hirundinella which also occurred in lakes Cucao and Tarahuín. The diversity of the zooplankton community varied across these lakes. The presence of Diaptomus diabolicus (Tumeodiaptomus $d$. Dussart 1979) (Cucao, Huillinco and Tepuhueico) is noteworthy since this extends its geographical distribution to the south.
\end{abstract}

Key words: river basin, limnological characterization, humic lakes, Chiloé, southern Chile.

\section{RESUMEN}

Durante noviembre de 1996 y octubre de 1997 mensualmente se estudió la cuenca de cinco lagos húmicos localizados en la Isla de Chiloé: Lagos Natri, Tepuhueico, Tarahuín, Huillinco y Cucao. El estudio tuvo como objetivo conocer el área de la cuenca, la cuenca hidrográfica y las principales características físicas, químicas y biológicas de estos lagos húmicos. Se determinó el estado trófico, como también la carga actual y el balance másico de fósforo y nitrógeno total, en relación a actividades antrópicas. Los lagos Cucao y Huillinco se caracterizaron por presentar influencia marina. Todos los lagos tienen aguas de color marrón, causadas por las sustancias húmicas, que limitan la transparencia. El lago Natri es el más profundo $(58 \mathrm{~m})$, mientras que el Tepuhueico presentó la menor profundidad $(25 \mathrm{~m})$. Concentraciones de fósforo y nitrógeno total fluctuaron entre 23,5 y $35 \mu \mathrm{g} \mathrm{L} \mathrm{L}^{-1}$ y 197 y $380 \mu \mathrm{g} \mathrm{L}-1$ en los lagos Natri, Tepuhueico y Tarahuín. Mientras que los lagos Cucao y Huillinco mostraron para el nitrógeno y fósforo concentraciones extremadamente altas, para el nitrógeno total (promedio anual > $3.000 \mu \mathrm{g} \mathrm{L}^{-1}$ ) y para el fósforo $\left(223\right.$ y $\left.496 \mu \mathrm{g} \mathrm{L}^{-1}\right)$ clasificándolos como hipereutróficos. El lago Tarahuín registró la mayor diversidad fitoplanctónica con 55 especies. En los lagos Cucao y Tarahuín, destaca la presencia de Ceratium hirundinella. La comunidad zooplanctónica mostró diferencias en la diversidades de especies en los lagos estudiados. En los lagos Cucao, Huillinco y Tepuhueico la presencia de Diaptomus diabolicus (= Tumeodiaptomus $d$. Dussart 1979), amplía su distribución geográfica hacia el sur.

Palabras clave: cuenca hidrográfica, caracterización limnológica, lagos húmicos, Chiloé, Sur de Chile.

\section{INTRODUCTION}

The Great Island of Chiloé belongs to the archipelago of Chiloé, which extends $180 \mathrm{~km}$ from north to south in a straight line, and is thus the second largest island of South America, after Tierra del Fuego. This island is crossed by a continuation of the continental Coastal Range which is interrupted by the Chacao channel separating the island from the 
continent on the north. To the east the island is separated from the continent by the Ancud and Corcovado gulfs.

Little information is available about the freshwater bodies on Chiloé Island. Campos et al. (1984) studied the macrozoobenthos and fish communities of some rivers on this island while Hedin \& Campos (1991) compared the watersheds of two contrasting environments including some streams on Chiloé Island. Campos et al. (1996) have studied the geographic significance of the distribution of the native fish species, Cheirodon australe in Lake Tarahuín. However, there is no detailed information on the limnology of the freshwater bodies of this Island and only in recent years have various lakes and rivers been studied. In addition to the present work, the investigations of Roberto Prado-Fiedler et al. and José Arenas et al. (unpublished results) should also be mentioned.

The objective of the study reported here was to investigate the catchment area of each river basin and the main physical, chemical and biological characteristics, of five humic lakes located in Chiloé Island: Lakes Natri, Tepuhueico, Tarahuín, Huillinco and Cucao. Based on the concentrations of phosphorus and nitrogen, and using the models of Ryding \& Rast (1992) and Vollenweider (1976), the actual loadings and mass balances of phosphorus and nitrogen in these lakes were measured. Due to the human influences on many of the lakes of Chiloé Island during recent decades, the information given here represents a basis for future studies and planning of sustainable management.

\section{MATERIAL AND METHODS}

\section{Study site}

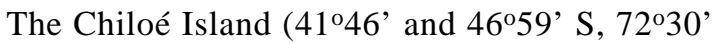
to $75^{\circ} 26^{\prime} \mathrm{W}$ ) is located within an oceanic ecological region with Mediterranean influence (di Castri 1968). The rainfall is 2.000-2.500 $\mathrm{mm}$, relative humidity averages $84 \%$ (di Castri 1968, Subiabre \& Rojas 1994), with an historical annual average temperature of 10.5 ${ }^{\circ} \mathrm{C}$; minimum and maximum temperatures average $6.9{ }^{\circ} \mathrm{C}$ and $14.2{ }^{\circ} \mathrm{C}$, respectively (di Castri 1968).

The geological substrate generally corresponds to precambrian metamorphics and recent tertiary sediments located within the coastal range. In the western part of Chiloé Island brown podzolics soils predominate
(Brüggen 1950). Three overlapping drift layers are recognized ("Fuerte San Antonio, Intermedia y Llanquihue"), representing the last glaciation and two or more previous glaciations (Subiabre \& Rojas 1994).

The forests of Chiloé are dominated by Nothofagus nitida, $N$. dombeyi with an almost total absence of $N$. obliqua. There is a formation of "Ñadis" shrub associations of Drimys winteri and Embothrium coccineum, among other aquatic plants, partially submerged (Hoffmann 1999), and formations of $N$. obliqua and Laurelia sempervirens are found within the central valley. At higher altitudes, "alerces" (Fitzroya cupressoides) are prominent along with associations of $N$. antarctica and N. pumilio (Brüggen 1950).

The hydrographic basin of the River Cucao, at $840 \mathrm{~km}^{2}$ is the third largest on the island and contains two elongated, interconnected lakes: Huillinco and Cucao, which drain into the Pacific Ocean. Within this basin, the most important tributary is the River Bravo $\left(418 \mathrm{~km}^{2}\right)$ which drains from Lake Tepuhueico into Lake Huillinco and, en route, receives water draining Lake Tarahuín (Subiabre \& Rojas 1994).

\section{Hydrographic river basins}

To define the hydrographic river basins of lakes Natri, Tepuhueico, Tarahuín, Cucao and Huillinco (Fig. 1), topographic information was obtained from maps 1:50.000 IGM (Instituto Geográfico Militar) (Isla Lemuy, Chonchi, Rivers Anay and Cucao). The data base was digitalized in Autocad R12, and worked with the Geographic Information System (SIG) Idrisi, to obtain information on surface areas, length of channels and density of drainage in the basin.

\section{Land use}

The land uses of the five basins were identified through photo-interpretation of aerial photographs 1:20.000 (S.A.F. 1995), analysis and interpretation of satellite images and land slopes. The cartographic information was digitalized in Autocad and input to the SIG Idrisi to obtain the surface areas occupied by each land use in the basin.

\section{Morphometry of slope}

The slope is one of the physical characteristics that permit some processes such as soil erosion and land slips to become factors limiting the use of land. The slope cartography was analysed according to the method of Brunett 


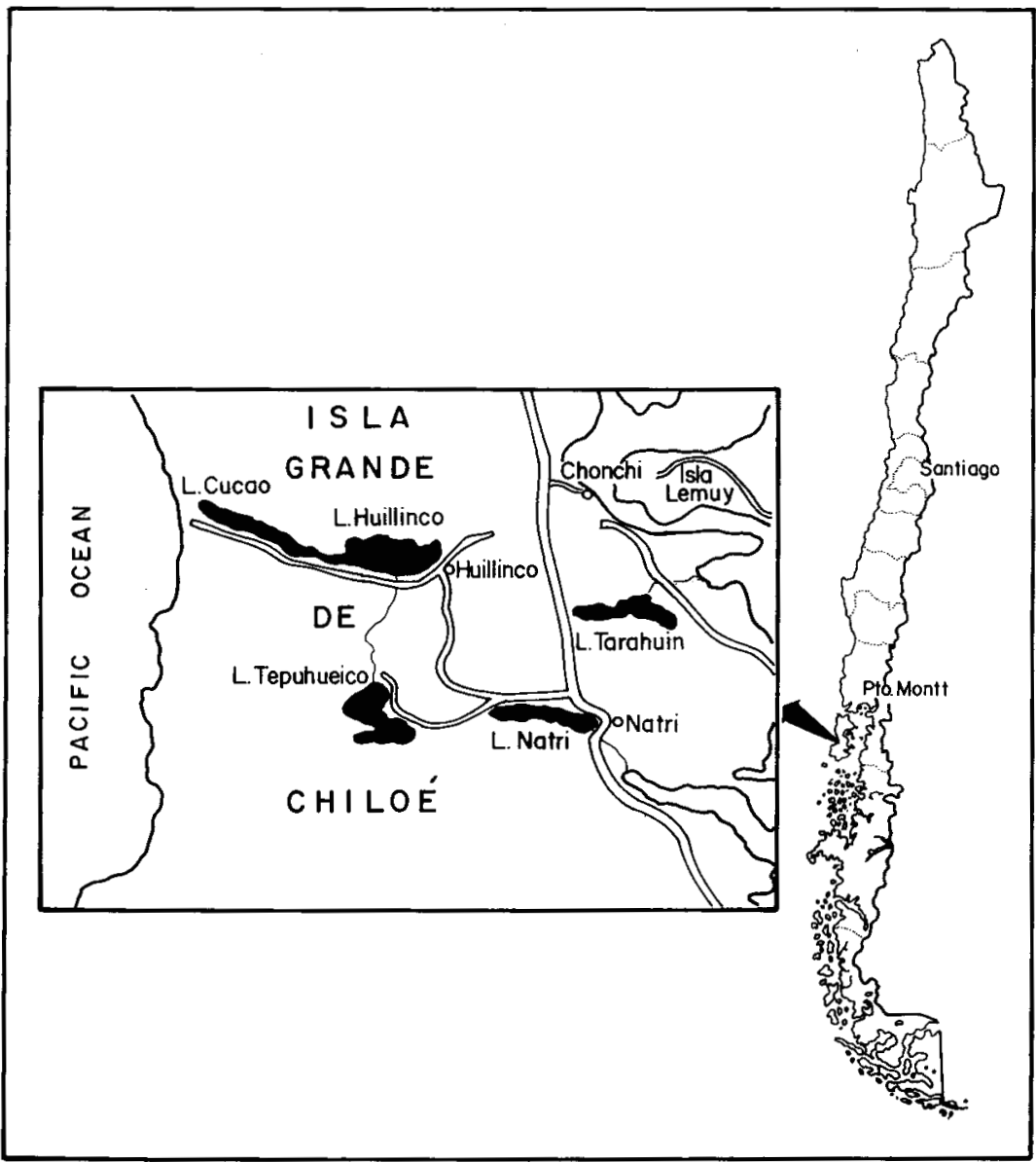

Fig. 1: Location of the five lakes studied on Chiloé Island: Lakes Natri, Tepuhueico, Tarahuín, Cucao and Huillinco.

Localización de los cinco lagos estudiados en la Isla de Chiloé: Lagos Natri, Tepuhueico, Tarahuín, Cucao y Huillinco.

(1963), which defines units that are morphometrically homogenous between certain thresholds given by the author (Table 1). The information on these maps was used to calculate the degree of inclination.

\section{Morphometry of lakes}

To assess hydrological and morphometric parameters, various maps of 1:50.000 IGM were used. Morphometric bathymetry was determined using a Lowrence echosounder X16 of $192 \mathrm{Khz}$ frequency.

\section{Field measurements}

Routine physical, chemical and biological sampling was carried out monthly in all five lakes from November 1996 to October 1997 at a central sampling station in each lake.
Samples were obtained using a Van Dorn bottle (volume $5 \mathrm{~L}$ ) at three depths representing the surface, middle and bottom of the lakes: Natri $(0.1,25,50 \mathrm{~m})$, Tepuhueico $(0.1,8,17 \mathrm{~m})$, Tarahuín $(0.1,15,30 \mathrm{~m})$, Huillinco $(0.1,22,45 \mathrm{~m})$ and Cucao $(0.1,8$, $16 \mathrm{~m})$. Additionally chemical samples were obtained from the inflows to each lake.

\section{Physical measurements}

Temperature profiles were obtained using a Kahlsico bathythermograph with an accuracy of better than $0.2{ }^{\circ} \mathrm{C}$. Water transparency was measured at midday with a standard $20 \mathrm{~cm}$ diameter Secchi disk, from the shady side of the boat. $\mathrm{pH}$ was measured with a $\mathrm{pH}$-meter (EXTECH, USA). The colour and turbidity were measured in the laboratory using a spectrophotometer at a wavelength of $440 \mathrm{~nm}$. 
TABLE 1

Surface, slopes and land use in the five Chiloé Island basins

Superficie, pendiente y uso de suelo en cinco cuencas de la Isla de Chiloé

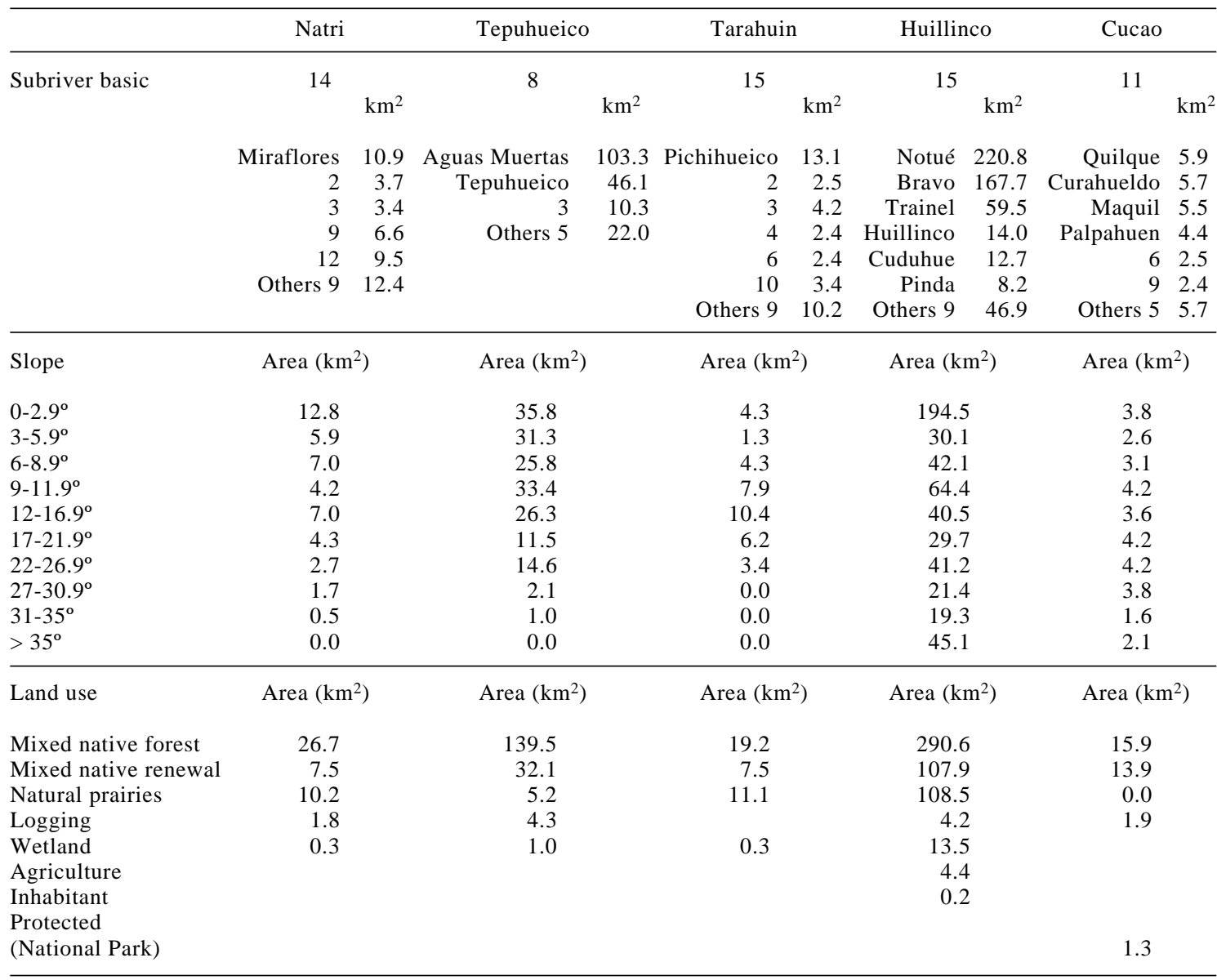

\section{Chemical measurements}

During each monthly sampling, a house in Villa Huillinco was used as a laboratory and a vehicle was adapted as a mobile laboratory. Thus, most of the chemical measurements were made in situ when the samples were obtained, either in the boat or in the mobile laboratory. The analyses of nitrogen and phosphorus compounds were made in the laboratory house on the day of sampling, up to the point of digestion and evaporation, and were then immediately sent at an optimal temperature, by bus or car to the laboratory of the Universidad Austral de Chile. Chemical analyses followed the methods described by Eaton et al. (1995) and are described only briefly here. Dissolved oxygen concentrations were determined by Winkler titration. For orthophosphate $\left(\mathrm{PO}_{4}-\mathrm{P}\right)$ and total phosphorus (TP) the molybdenum blue method was used, but with a preliminary acid-peroxide digestion for TP (Ammbühl \& Schmidt 1965). The concentration of $\mathrm{NO}_{3}-\mathrm{N}$ was determined as the difference between the concentrations of $\mathrm{NO}_{3}-\mathrm{N}+\mathrm{NO}_{2}-\mathrm{N}$ and $\mathrm{NO}_{2}-\mathrm{N}$. Analysis for $\mathrm{NO}_{2}-\mathrm{N}+\mathrm{NO}_{3}-\mathrm{N}$ involved reduction of $\mathrm{NO}_{3}-\mathrm{N}$ to $\mathrm{NO}_{2}-\mathrm{N}$ with sodium salicylate and salt of Seignette, prior to analysis as for $\mathrm{NO}_{2}-\mathrm{N}$. The analysis of $\mathrm{NO}_{2}-\mathrm{N}$ involved the formation of a diazonium salt complex which reacted with chromotropic acid prior to colourimetric analysis. The indophenol blue method was used for analysis of $\mathrm{NH}_{4}-\mathrm{N}$, and total nitrogen concentrations were determined as the sum of concentrations of Kjeldahl nitrogen $+\mathrm{NO}_{3}-\mathrm{N}+\mathrm{NO}_{2}-\mathrm{N}$.

Organic and inorganic seston (particulate matter) were quantified by filtering $1 \mathrm{~L}$ of lake water through a previously tared fiber glass filter $(0.45 \mu \mathrm{m})$, dried at $60{ }^{\circ} \mathrm{C}$ for $24 \mathrm{~h}$. The 
dry weight of organic particulate material was obtained by weight difference. The filter was incinerated for $6 \mathrm{~h}$ in a Muffle at $550{ }^{\circ} \mathrm{C}$ until only ashes remained; the inorganic fraction of the seston was obtained by weight difference. Calcium, magnesium, sodium and potassium were measured using an atomic absorption spectrophotometer, Perkin Elmer 2380. Chloride concentration was determined using the mercuric nitrate method. Sulphate was measured by turbidimetry. Alkalinity was determined by titration using $0.025 \mathrm{~N}$ hydrochloric acid with bromocresol greenmethyl red as indicator. Bicarbonate was calculated from alkalinity.

To determine the nutrient concentrations in the rainwater, a $1 \mathrm{~m}^{2}$ surface automatic collector, connected to a Pyrex glass container, was set up in each river basin during the field trip. Rainwater was cold preserved until its analysis, and total phosphorus and nitrogen concentrations were determined according to the methods described above.

Chlorophyll $a$ was determined by filtration of $3 \mathrm{~L}$ of lake water through Millipore glass fiber $(\mathrm{GF} / \mathrm{C})$ filters and extraction of pigment from the filters with $90 \%$ acetone. Absorbance of the extract was measured with a Shimadzu UV-150-02 spectrophotometer and the equations of Scor-Unesco (1969) were then used to estimate concentrations of chlorophyll $a$ after correction for accessory pigments (chlorophylls $b$ and $c$ ).

Phytoplankton was collected with a Van Dorn bottle at $0.1,3,5,10$ and $15 \mathrm{~m}$, fixed with Lugol's iodine (1\% final concentration) in 100 $\mathrm{mL}$ water samples, and counted using a Zeiss Inverted Microscope according to the standard Utermöhl technique (1958). Zooplankton was collected using a Ruttner net with a $10.4 \mathrm{~cm}$ mouth opening and mesh size of $90 \mu \mathrm{m}$. Vertical hauls were carried out at different depths: Natri and Tarahuín (30-20, 20-15, 15$10,10-6,6-3,3-0 \mathrm{~m})$, Tepuhueico $(20-15,15-$ 10, 10-6, 6-3, 3-0 m), Huillinco (50-30, 30-20, $20-15,15-10,10-6,6-3,3-0 \mathrm{~m})$ and Cucao (15$10,10-6,6-3,3-0 \mathrm{~m})$. The samples were fixed with formaldehyde-sugar to a final concentration of $4 \%$ (Haney \& Hall 1973), and counted in Bogorov chambers under 40-100 x.

The annual loads of phosphor and nitrogen were calculated according to the equation of Ryding \& Rast (1992, eq. 1). The mass balance of phosphorous and nitrogen were calculated according the equation of Vollenweider (1976, equation 2 ):

$$
L=L_{T}+L_{D S}+L_{D D}+L_{A}+L_{G}+L_{S}
$$

Equation 1 (modified after Ryding \& Rast 1992): $L=$ total load, $L_{T}=$ annual load of the inflows, $L_{D S}=$ direct and diffuse load of sewage waters, $L_{A}=$ atmospheric contribution by rain water, $L_{G}=$ load through the fish farming entries, $L_{S}=$ liberation of nutrients from the sediment, and $L_{T}=$ annual load of the inflows.

$$
L[p, n]=\frac{Q_{1}[P]_{1}+Q_{2}[P]_{2}+\ldots \ldots+Q_{n}[P]_{n}}{A_{o}}
$$

where: $L[p, n]$ is the load of phosphorus or nitrogen in $\mu \mathrm{g} \mathrm{m}^{-2}$ year $^{-1}, Q_{1}$ the annual flow of the inflow, $P$ the concentration of phosphorus or nitrogen from the corresponding inflow in the flow, and $A_{o}$ the area of the lake.

$L_{D S}=$ direct and diffuse load of sewage waters $J_{A}=\mathrm{K}\left(\mathrm{kg}_{\text {per capita }}{ }^{-1}\right.$ year $\left.^{-1}\right) N(1-R s) T$ year $\left.^{-1}\right)$

where: $J_{A}$ is the artificial phosphorus or nitrogen supply, $\mathrm{K}$ is a constant that in the case of phosphorus $K=0.8 \mathrm{~kg}$ by person year ${ }^{-1}$, and for nitrogen $K=3.8 \mathrm{~kg}_{\text {year }}{ }^{-1}$ (Dillon \& Rigler 1974). $N$ is the number of inhabitants, $R s$ the retention coefficient of total phosphorus per septic tank according to the filtration capacity of the soil (to filter bed) (Brandes et al. 1974). A $R s$ of 0.30 was calculated per septic tank by Brandes et al. (1974). $T$ is the average number of days of use by the inhabitants per year.

$$
\begin{aligned}
& L_{A}=\text { atmospheric contribution by rain water } \\
& L[p, n]=P p, n([p, n] / A o)
\end{aligned}
$$

where: $L[p, n]$ is the load of phosphorus or nitrogen in $\mu \mathrm{g} \mathrm{m}^{-2}$ year-1, $P p, n$ the annual precipitation of phosphorus or nitrogen on the lake, $[p, n]$ the average concentration of phosphorus or nitrogen in the rain water. Ao the area of the lake.

$$
\begin{gathered}
L_{G}=\text { load through the fish farming centres } \\
R=P+A-(S+M)
\end{gathered}
$$

where: $R$ is the supply of phosphorus or nitrogen to the lake, $P$ the content of phosphorus or nitrogen in the smolts production, $A$ is the content of phosphorus or nitrogen in the smolts leaving the fish farm, and $M$ is the content of phosphorus or nitrogen in those which died. The nutrient loads from the fish farming were calculated according to the amounts of food used in the production of smolts during the year. Chemical analyses were conducted to quantify the amounts of phosphorus and nitrogen present directly in the 
food. The content of phosphorus and nitrogen in the fish was also considered, and such data were taken from Rodriguez (1993). The calculations of the quantities of food used in the production process were made using a conversion factor of 1.5 .

$L_{S}=$ liberation of nutrients from the sediment

where $L s$ is considered as internal load of phosphorus or nitrogen $\left(L_{\text {int }}\right)$ and was calculated according to the mass balance described in the equation 2.

$$
L_{\text {int }}=L_{\text {out }}-L_{\text {ext }} \pm T P
$$

Equation 2 (Vollenweider 1976)

where $L_{\text {int }}=$ internal load of total phosphorus or nitrogen during a period of study, $L_{\text {out }}=$ loss of total phosphorus or nitrogen in the water column during a period of study, $L_{e x t}=$ external load of total phosphorus or nitrogen in the water column during a period, and $\pm T P=$ difference positive or negative in the total phosphorus or nitrogen content in the water column during the annual period of study.

\section{RESULTS}

Hydrographic system and land uses in the different River Basin: Lake Natri

The catchment area of Lake Natri drains a total area of $46.5 \mathrm{~km}^{2}$ on the central eastern slope of Chiloé Island, and empties through the River Natri which ends in the inner sea. Fourteen subbasins were recognized (Fig. 2) which, according to the classification of Strahler (1987), comprise a network of 25 first order and six second order

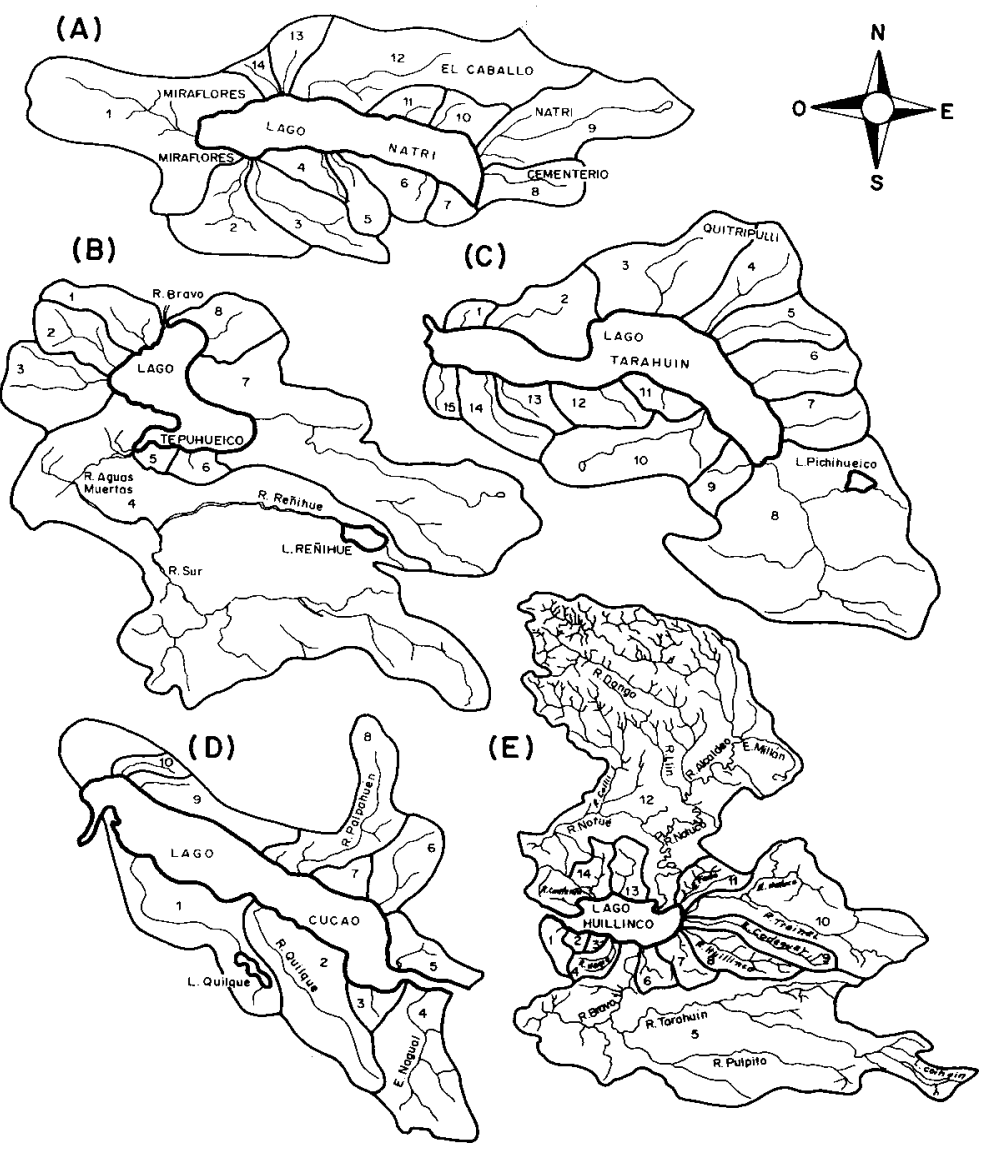

Fig. 2: Hydrology of the catchment area of the five lakes studied on Chiloé Island: (A) Natri, (B) Tepuhueico, (C) Tarahuín, (D) Cucao and (E) Huillinco.

Hidrología de las cuencas hidrográficas los cinco lagos estudiados en la Isla de Chiloé: (A) Natri, (B) Tepuhueico, (C) Tarahuín, (D) Cucao y (E) Huillinco. 
rivers. The Miraflores stream, located in the north-west, constitutes the largest sub-river basin (Table 1). The Natri basin in general has moderate slopes $\left(0.5-8.9^{\circ}\right)$ (Table 1$)$. Some erosive processes were observed in areas with slopes greater than $17^{\circ}$ (southern slopes) caused by change in the land use (grazing of cattle)

\section{Lake Tepuhueico}

The basin of this lake comprises part of the hydrographic system of Lake Cucao and drains the south-western slope to $42^{\circ} 47^{\prime} \mathrm{S}$. The basin covers a surface of $182.1 \mathrm{~km}^{2}$. Lake Tepuhueico receives two important inflows (Fig. 2): Aguas Muertas and Tepuhueico, and itself empties towards the north through the River Bravo which flows into Lake Huillinco. In the basin of Lake Tepuhueico eight sub-river basins were recognized (Fig. 2) and this hydrographic network consists of 32 first order, 10 second order and 1 third order river, the Aguas Muertas, which is exceptional for its $103.3 \mathrm{~km}^{2}$. The sub-river basins of the River Tepuhueico are the second most extensive (Table 1). The basin of Lake Tepuhueico has a morphometry of predominantly moderate slopes with $52 \%$ of the territory less than $12^{\circ}$.

\section{Lake Tarahuín}

This lake receives drainage from the eastern slope of the Huillinco-Cucao hydrographic system to $42^{\circ} 43^{\prime} \mathrm{S}$. With a catchment area of $38.2 \mathrm{~km}^{2}$ the lake is orientated in a north-south direction and drains through the River Tarahuín to the River Bravo. Fifteen smaller sub-river basins (Fig. 2), corresponding to rivers and streams have been recognised in this basin. Twenty-two first order and 4 second order streams make up the hydrographic network. The most important of these is the River Pichihueico (Table 1), draining the south-eastern slope. The second most important are those numbered 3 (north slope) and 10, the latter receiving its water from a small lagoon. None of the twelve remaining sub-basins exceed $2.5 \mathrm{~km}^{2}$ in surface area and are primarily seasonal run-off waters. The Tarahuín basin has predominantly moderate slopes $\left(<12^{\circ}, 50 \%\right.$ of the surface); areas with very strong slopes $\left(22-26.9^{\circ}\right)$ were found only in the $8.9 \%$ of the area (Table 1 ).

\section{Lake Huillinco}

Drains the north-eastern slope of the HuillincoCucao hydrographic system to $42^{\circ} 30^{\prime} \mathrm{S}$. In this basin there are 15 sub-basins (Fig. 2), of rivers and streams forming a particularly dense network which consists of 110 first order and 50 second order water courses. The most important of these is the River Notué, which drains $43 \%$ of the territory on the north slope. The rivers Bravo and Trainel are also significant sub-basins (Table 1). The basin of Lake Huillinco shows a predominance of gentle slopes $\left(0.5-2.9^{\circ}\right)$ (Table 1) but in the north of the area there are steep slopes associated with the mountains of the Coastal range. In the south and east, gentle to moderate slopes predominate, associated with platforms and fluvio-glacial terraces.

\section{Lake Cucao}

The basin of Lake Cucao drains the western slope of its hydrographic network to $42^{\circ} \mathrm{S}$; with a basin covering $33.2 \mathrm{~km}^{2}$. It lies perpendicular to the coastline and drains through the River Cucao to the Pacific Ocean, which exerts a strong marine influence on lakes Cucao and Huillinco (Fig. 1). Eleven subbasins were recognised in the basin of Lake Cucao (Fig. 2), comprising 18 first, six second and one third order streams, the most important of which is the River Quilque, draining the south slope. The rivers Curahueldo, Maquil and Palpahuén are the next most important subbasins (Table 1). The Cucao basin is characterised by slopes over $12^{\circ}(50 \%)$ (Table 1) whose maximum altitudes reaches 800 m.a.s.l. at the north- western end and the minimum ( $5 \mathrm{~m}$ of altitude) is at its inflow.

\section{Land use}

Most of river basins (nearly $70 \%$ ) are covered with mature or regenerating native forest consisting of species such as: "canelo" (Drimys winteri), "Tepú" (Tepualia stipularis), "Luma blanca" (Myrceugenia chrysocarpa), "Olivillo" (Aextoxicon punctatum), "Avellano" (Gevuina avellana), "Mañío" (Podocarpus nubigenana (male) and Saxe-Gothea conspicua (female)) and "Coigüe" (Nothofagus nitida, N. dombeyi, $N$. antarctica and $N$. pumilio). This type of forest cover reaches around $94 \%$ in the basin of Lake Tepuhueico. On the other hand, in the basins of lakes Natri, Tarahuín and Huillinco about $22 \%$ is natural prairie. Associated with Lakes Natri, Tepuhueico, Tarahuín and Huillinco there are small areas of wetland which are of importance (Table 1). In the basin of Lake Cucao $4.1 \%$ of the outstanding landscape is destined to be a National Park. Only in the basin of Lake Huillinco, is there a very small percentage $(0.03 \%)$ covered by 
human habitation (Table 1). Huillinco recognized as a Village by the National Institute of Statistics, is located on the eastern shore of the lake with 88 houses inhabited by a population of 336 .

\section{Limnological characterization}

The results presented in this section as annual averages or means correspond to the arithmetic mean calculated for the study period from November 1996 to October 1997. The trophic status mentioned by the authors in different sections of the text was based on data given by Wetzel (1983).

\section{Morphometric features}

Table 2 and Fig. 3A-E show the morphological features of all the lakes. Lake Natri has an elongated form, extending from east to west, and drains through the River Natri. It is predominantly shallow $(<20 \mathrm{~m})$ around the margins. Lake Tepuhueico extends in a northwest to south-eastern orientation and drains via the River Bravo. It has an irregular rounded shape with a constriction in the middle where it reaches its maximum depth. Most of this lake is more than $15 \mathrm{~m}$ deep (Fig. 3B). Lake Tarahuín lies in an east - west direction, and drains to the west via the River Tarahuín, which joins the

TABLE 2

Locations and morphometric parameters of Lakes Natri, Tepuhueico, Tarahuín, Cucao and Huillinco

Localización y parámetros morfométricos de los lagos Natri, Tepuhueico, Tarahuín, Cucao y Huillinco

\begin{tabular}{|c|c|c|c|c|c|}
\hline & Natri & Tepuhueico & Tarahuín & Huillinco & Cucao \\
\hline Latitude & $42^{\circ} 47^{\prime} \mathrm{S}$ & $42^{\circ} 47^{\prime} \mathrm{S}$ & $42^{\circ} 43^{\prime} \mathrm{S}$ & $42^{\circ} 40^{\prime} \mathrm{S}$ & $42^{\circ} 38^{\prime} \mathrm{S}$ \\
\hline Longitude & $73^{\circ} 50^{\prime} \mathrm{W}$ & $73^{\circ} 58^{\prime} \mathrm{W}$ & $73^{\circ} 45^{\prime} \mathrm{W}$ & $73^{\circ} 57^{\prime} \mathrm{W}$ & $74^{\circ} 40^{\prime} \mathrm{W}$ \\
\hline Altitude (m) & 39.0 & 25.0 & 66.0 & 13.0 & 10.0 \\
\hline Volume $\left(\mathrm{km}^{3}\right)$ & 0.273 & 0.128 & 0.170 & 0.395 & 0.127 \\
\hline Surface area $(A o)\left(\mathrm{km}^{2}\right)$ & 7.8 & 14.3 & 7.7 & 19.1 & 10.6 \\
\hline Catchment area $(A d)\left(\mathrm{km}^{2}\right)$ & 46.5 & 182.1 & 38.1 & 529.8 & 33.2 \\
\hline Maximum length $\left(l_{m}\right)(\mathrm{km})$ & 6.3 & 5.2 & 6.4 & 8.1 & 7.9 \\
\hline Maximum breadth $\left(b_{m}\right)(\mathrm{km})$ & 1.3 & 3.1 & 1.5 & 3.2 & 1.8 \\
\hline Minimum breadth $(\mathrm{km})$ & 0.6 & 1.9 & 0.5 & 0.8 & 0.7 \\
\hline Mean breadth $(b)(\mathrm{km})$ & 1.2 & 2.5 & 0.9 & 1.9 & 1.1 \\
\hline Maximum depth $(\mathrm{Zm})(\mathrm{m})$ & 58.0 & 25.0 & 33.0 & 47.0 & 25.0 \\
\hline Mean depth $(Z)(\mathrm{m})$ & 35.0 & 9.0 & 22.2 & 20.7 & 12.0 \\
\hline Relative depth $(\mathrm{Zr})(\%)$ & 1.8 & 0.6 & 1.1 & 1.0 & 0.7 \\
\hline Shore line $(L)(\mathrm{km})$ & 16.4 & 24.7 & 20.0 & 25.9 & 22.9 \\
\hline Development of shore line $\left(D_{L}\right)$ & 1.7 & 1.8 & 2.0 & 1.7 & 2.0 \\
\hline Ad/Ao & 6.0 & 12.7 & 4.9 & 27.7 & 3.1 \\
\hline Ratio of mean to maximum depth $Z: Z m$ & 0.6 & 0.4 & 0.7 & 0.4 & 0.5 \\
\hline Development of volume & 1.8 & 1.1 & 2.0 & 1.3 & 1.4 \\
\hline
\end{tabular}




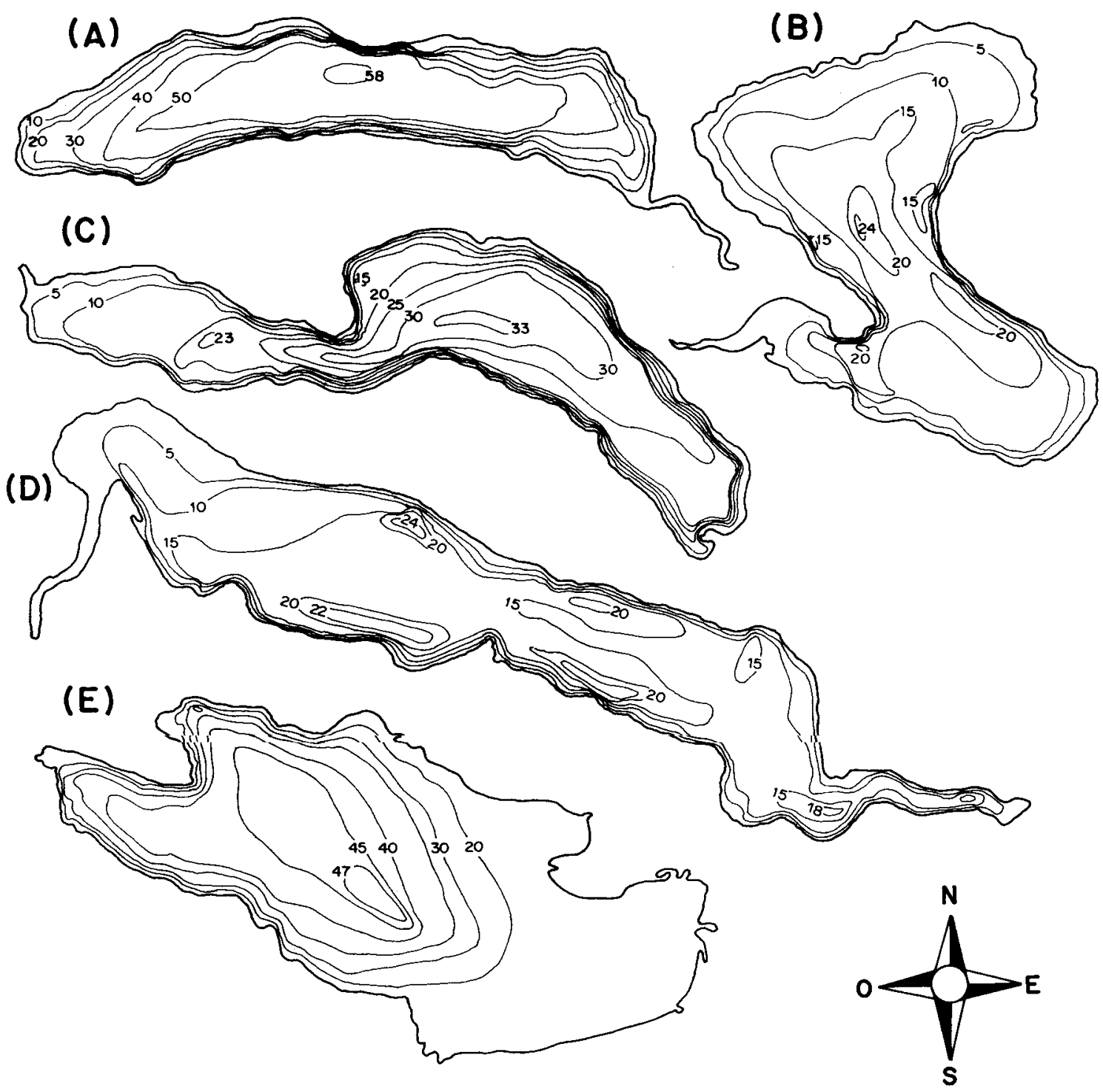

Fig. 3: Bathymetric maps of the lakes: (A) Natri, (B) Tepuhueico, (C) Tarahuín, (D) Cucao y (E) Huillinco.

Mapas batimétricos de los lagos: (A) Natri, (B) Tepuhueico, (C) Tarahuín, (D) Cucao y (E) Huillinco.

River Bravo. This lake is also elongated with a small constriction around the middle, and is predominantly less than $15 \mathrm{~m}$ deep (Fig. 3C). Lake Huillinco extends from east to west, with an irregular shape of an almost rounded receptacle with depth diminishing regularly towards the coast where it drains to Lake Cucao through the channel Caldera (Fig. 3E). Lake Cucao extends in a north-west to southeastern direction and empties into the Pacific Ocean through the River Cucao. The lake has an elongated shape with a predominance of zones less than $15 \mathrm{~m}$ but the distribution of depths was irregular on the middle of the lake (Fig. 3D).

\section{Physical characterization}

The seasonal cycles of water temperature from the surface $(0.1 \mathrm{~m})$ to the bottom are shown in Fig. 4. The lakes showed similar temperatures ranging from $8.6{ }^{\circ} \mathrm{C}$ (Huillinco, July, $0.1 \mathrm{~m}$ ) to $20.5{ }^{\circ} \mathrm{C}$ (Cucao, January, $0.1 \mathrm{~m}$ ). Of the freshwater lakes Lake Tarahuín and especially 


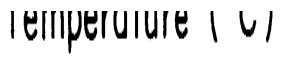

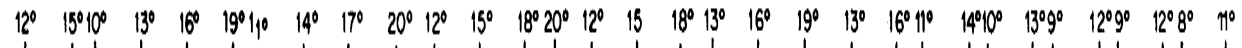

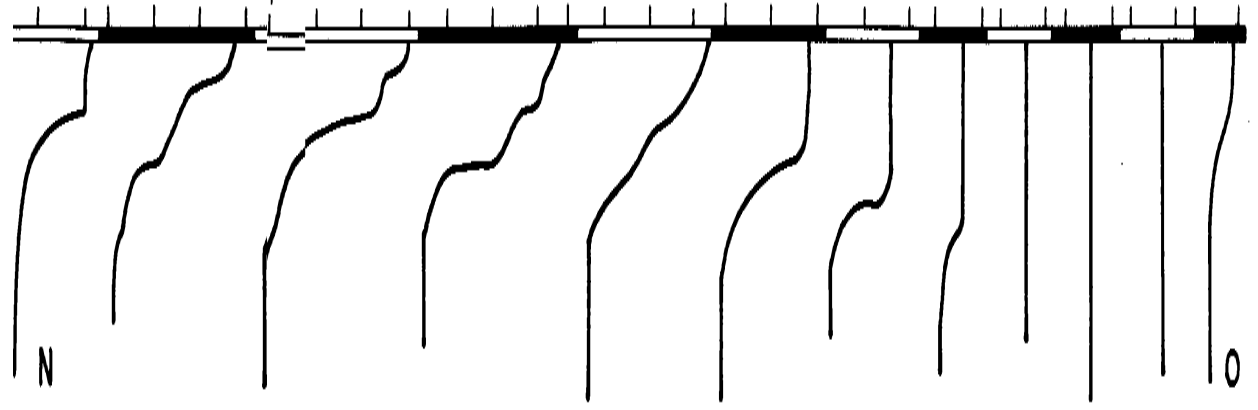

IA

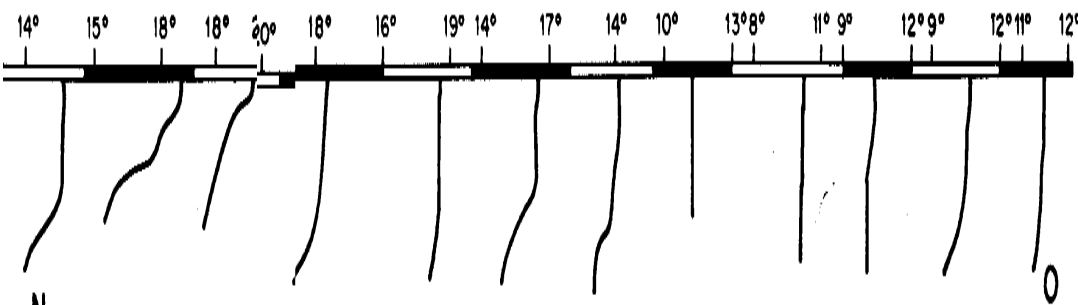

N

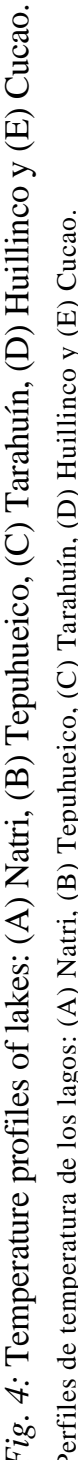
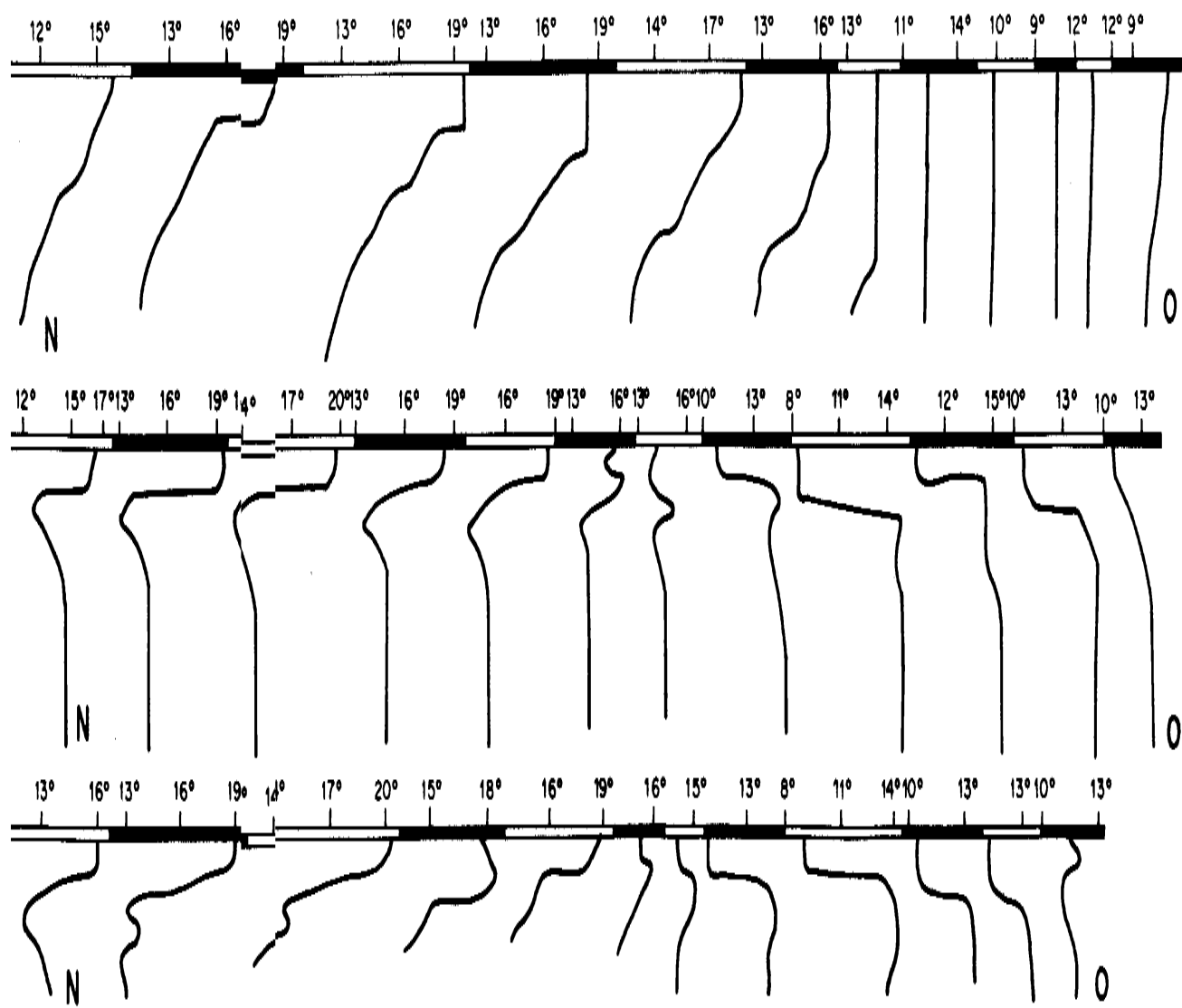
Lake Natri, can be classified as monomictic temperate, since they exhibited a winter circulation, and thermal stratification throughout the summer (Fig. 4A, 4C). During winter, Lake Natri was isothermal throughout the water column between 11.6 and $10.0{ }^{\circ} \mathrm{C}$ (Fig. 4A), very similar to Lake Tarahuín. Thermal stratification began in the middle of spring (October) and lasted until autumn. In Lake Natri the depth of the thermocline varied between 5 and $25 \mathrm{~m}$ while the hypolimnium temperature remained between $9.5-12.0^{\circ} \mathrm{C}$. The summer stratification in Lake Tarahuín was similar to that in Lake Natri (Fig. 4C). Lake Tepuhueico was different in that there was no typical thermal stratification during summer (Fig. 4B). The maximal temperature difference between the surface and the bottom of the lake during summer was only $3{ }^{\circ} \mathrm{C}$. Throughout the winter (June-August) the lake was isothermal from 9.4 to $11.3{ }^{\circ} \mathrm{C}$.

The thermal regimes of lakes Cucao and Huillinco showed two patterns (Fig. 4D, 4E). The first was observed from the end of November to the end of March (springsummer) when the surface temperature varied between 16.5 and $20.0^{\circ} \mathrm{C}$. From 9 (10) $\mathrm{m}$ the temperature decreased abruptly by around 5 to $7{ }^{\circ} \mathrm{C}$ but below $10 \mathrm{~m}$ rose again by 2 to $3{ }^{\circ} \mathrm{C}$ within two or three meters (Fig. 4D, 4E). Below $20 \mathrm{~m}$, in the case of Lake Huillinco, the temperature was stable at approximately 14.5 ${ }^{\circ} \mathrm{C}$. In this profile the thermocline was recorded at between 5 and $10 \mathrm{~m}$. In the second pattern an inverted thermocline was observed from autumn to the onset of spring (April-October). The surface temperature $\left(8.6-16^{\circ} \mathrm{C}\right)$ down to 5 to $8(10) \mathrm{m}$ deep was colder than water in the middle of the column while below this depth the temperature increased again by 2 to $7{ }^{\circ} \mathrm{C}$, reaching maximum differences in July (Fig. 4D, 4E). Below $20 \mathrm{~m}$ in Lake Huillinco the temperature was stable down to the bottom.

In all the lakes the transparency measured with the Secchi disk was very low (Fig. 5), with a minimum of $2.5 \mathrm{~m}$ in the freshwater Lake Tepuhueico (July, Fig. 5), and maximum in lakes Natri and Tarahuín with ca. $6.4 \mathrm{~m}$. In lakes Cucao and Huillinco the transparency was even lower and ranged between 1.9 and $3.6 \mathrm{~m}$ (Fig. 5D, 5E).

The water in all the lakes was brown in colour indicating dissolved organic acid matter such as humic acid of vegetable origin. The colour of lakes Natri, Tepuhueico and Tarahuín fluctuated between 8.3 Unid Pt.-Co. (Tarahuín) to 170 Unid Pt.-Co. (Tepuhueico) (Table 3). Lakes Natri and Tarahuín showed similar annual averages compared to Lake Tepuhueico, whereas lakes Cucao and Huillinco exhibited slightly more densely coloured waters than the freshwater lakes.

\section{Chemical characterization}

The $\mathrm{pH}$ values indicated acidity in all the lakes. The lowest annual average $\mathrm{pH}$ was measured in Lake Tepuhueico (Table 3). In general, the range of $\mathrm{pH}$ in the freshwater lakes remained below neutrality, while the values in lakes Cucao and Huillinco were nearer to neutrality. The highest conductivities were measured in lakes Cucao and Huillinco, resulting from the marine influence (Table 3). In both these lakes the conductivity showed a strong vertical gradient. In Lake Cucao the annual average conductivity at the surface was $2.461 \mu \mathrm{Scm}^{-1}$; whereas at the bottom, the corresponding value was $27.684 \mu \mathrm{Scm}^{-1}$. In Lake Huillinco the annual average conductivity was higher, at $3.512 \mu \mathrm{Scm}^{-1}$ and $40.658 \mu \mathrm{Scm}^{-1}$ at the surface and bottom, respectively. The salinity at the bottom of lakes Cucao and Huillinco had an annual average of 19 and $29 \%$, respectively.

In all the lakes there was a decrease in the oxygen concentration from the surface to the bottom. In lakes Natri and Tarahuín the maximum monthly average oxygen concentration $\left(11 \mathrm{mg} \mathrm{L}^{-1}\right)$ was measured during September (Natri) and December (Tarahuín). The minimum concentration among the freshwater lakes was measured in Lake Tarahuín where, from March to May, the concentration at the bottom was $0.2 \mathrm{mg} \mathrm{L}^{-1}$. Lakes Cucao and Huillinco showed large differences in their oxygen concentrations within a vertical profile: at the surface $(0-3 \mathrm{~m})$ values of $10-11 \mathrm{mg} \mathrm{L}^{-1}$ were found, whereas the bottom was anoxic. An extreme condition was observed in Lake Huillinco, where there was no oxygen below $18 \mathrm{~m}$. In Lake Cucao below $14 \mathrm{~m}$ an annual average of only $1 \mathrm{mg} \mathrm{L}^{-}$ ${ }^{1}$ was measured.

The nitrate concentrations were very high. Among the freshwater lakes, Lake Natri showed the highest concentration (Table 3 ) and the lowest was found in Lake Tarahuín with a minimum in April of $65 \mu \mathrm{g} \mathrm{L}^{-1}$. In lakes Cucao and Huillinco nitrate concentrations (Table 3) were extremely high with an exceptional 7.658 $\mu \mathrm{g} \mathrm{L}^{-1}$ in Lake Huillinco (June). There was a vertical gradient throughout the year, with the higher concentrations in the bottom of the lake. Nitrite concentrations were low in lakes Natri and Tarahuín and highest in Lake Cucao (Table 

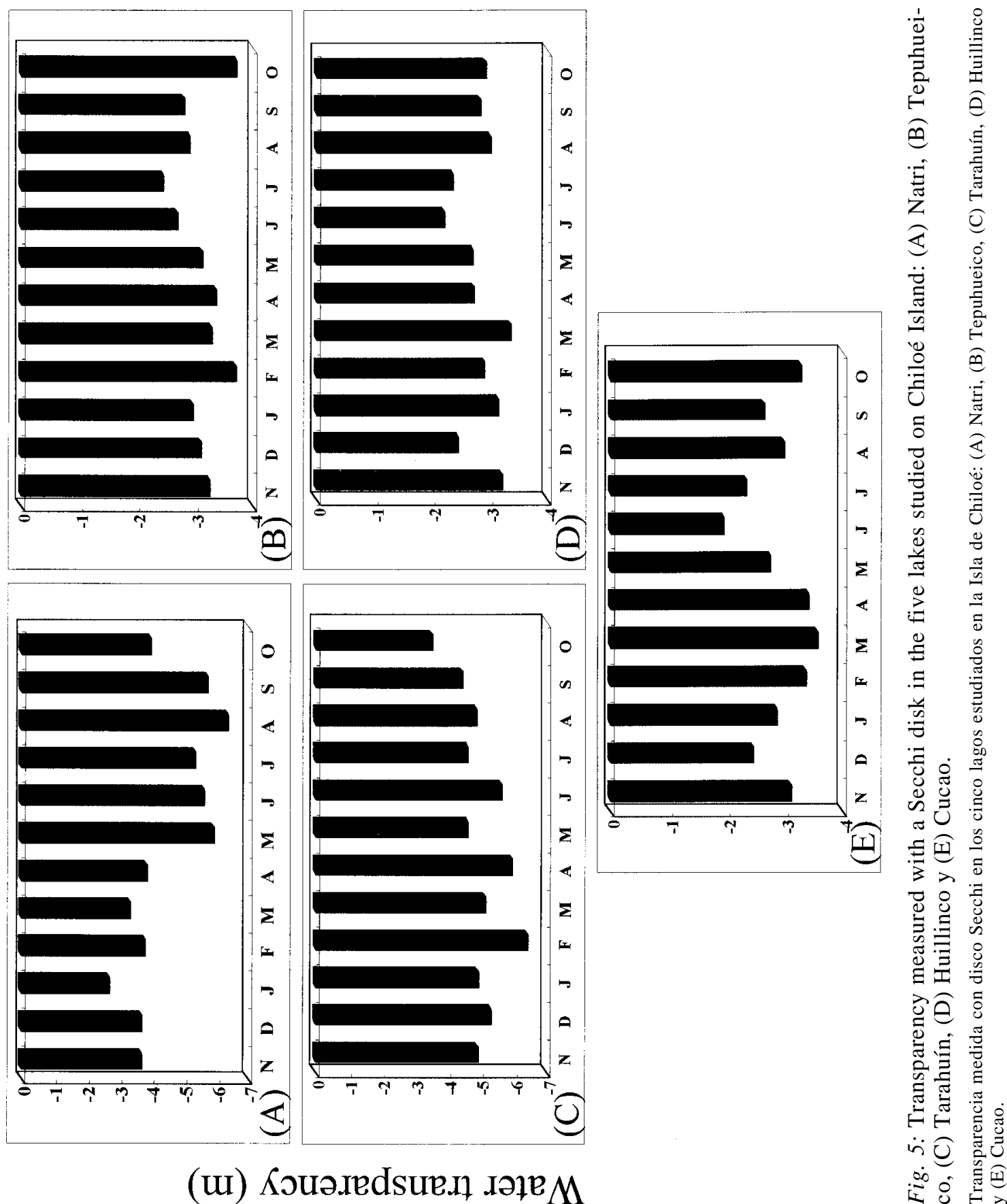

(u) Кэuәxеdsueı дәре $M$

$\infty$ 


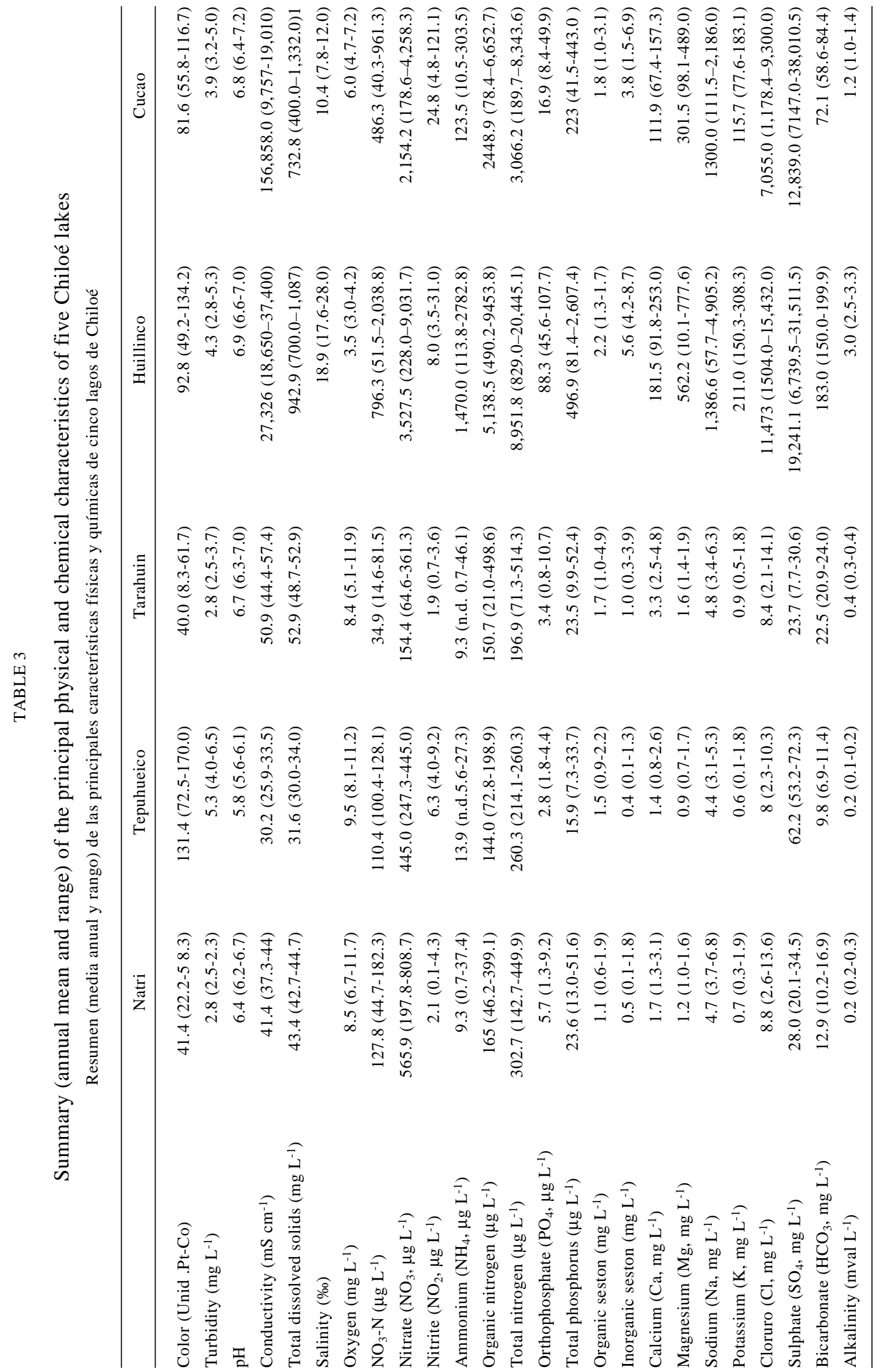


3), with a maximum of $44.7 \mu \mathrm{g} \mathrm{L}^{-1}$ (January). Among the freshwater lakes, ammonium concentrations were similar and not very high (Table 3). Lakes Cucao and Huillinco showed high ammonium concentrations and differences were observed between the surface (33.0 and $19.6 \mu \mathrm{g} \mathrm{L}^{-1}$ ) and bottom (279 and $2,798 \mu \mathrm{g} \mathrm{L}^{-}$ ${ }^{1}$ ), indicating a denitrification process. Among the freshwater lakes, the maximum concentration of organic nitrogen was found in lake Natri with an annual average of $165 \mu \mathrm{g} \mathrm{\textrm {L } ^ { - }}$ 1 , and the lowest in Lake Tepuhueico (Table 3, Fig. 6). Lakes Cucao and Huillinco had concentrations corresponding to hypereutrophic lakes and, in general, the organic nitrogen constituted a considerable portion of the total nitrogen (Fig. 6).

The highest annual average of orthophosphate among the freshwater lakes was observed in Lake Natri, with $5.7 \mu \mathrm{g} \mathrm{L}^{-1}$ (Table 3, Fig. 7). Lake Cucao had moderate to high concentrations of orthophosphate (Fig. 7), while a high annual concentration was measured in Lake Huillinco (Table 3). However, in the surface waters of both lakes (0.1-3 m) very low concentrations of orthophosphate were measured (annual average Huillinco $=$ of $3.1 \mu \mathrm{gL}^{-1}$ ) and in Lake Huillinco there was a strong vertical gradient, reaching an annual average of $164 \mu \mathrm{g}$ $\mathrm{L}-1$ at the bottom.

Among the studied freshwater lakes, total phosphorus exceeded the limit of mesotrophy, reaching similar concentrations in lakes Natri and Tarahuín (Table 3, Fig. 7). On the other hand, in Lake Cucao the total phosphorus exhibited extraordinarily high values even in the surface water, with an annual average of 169 $\mathrm{mgL}^{-1}$, as also in the deep water $\left(297 \mu \mathrm{g} \mathrm{L}^{-1}\right)$. A similar situation was observed in the surface water of lake Huillinco, but the concentrations were still higher in the middle and bottom of this lake, reaching annual averages of 606.4 and $731.0 \mu \mathrm{g} \mathrm{L}^{-1}$, respectively.

Their ionic compositions clearly differentiate lakes Natri, Tarahuín and Tepuhueico from the other two lakes. They had low concentrations of cations (calcium, magnesium, sodium and potassium) and anions (bicarbonate and chloride) (Table 3 ). Nevertheless, high sulphate concentrations were recorded in the lakes and in the rivers (Table 3). On the other hand, in lakes Huillinco and Cucao, very high concentrations of anions and cations were observed.

The concentrations of suspended sediment (particles smaller of $70 \mu \mathrm{m}$ ), or seston, were as low in the lakes as in the rivers and consisted mainly of organic matter. The alkalinity was also low.
Characterization of the lakes inflows and outflows

The main inflows and outflow of each lake were also studied (L. Villalobos unpublished results). Those inflows were chosen which contributed a permanent water supply to the lake and some of the characteristics of these rivers are summarized here. In the basin of Lake Natri the largest drainage area was that of river number 2 (Miraflores), and for Lake Tepuhueico the River Aguas Muertas stands out as having the largest drainage area and length (Fig. 2). In the basins of lakes Tarahuín and Cucao the river drainages were of moderate surface area while the largest drainage area was represented by the River Bravo with $167.7 \mathrm{~km}^{2}$ and, its tributary the outflow from Lake Tarahuín (River Tarahuín).

The inflows, in general, showed similar limnological characteristics. In the majority, the minimum temperature $\left(4.9^{\circ} \mathrm{C}\right.$ in the River Tepuhueico) was recorded in August (winter) and the maximum $\left(17.5{ }^{\circ} \mathrm{C}\right)$ in January (summer) in the River Bravo. Most of the rivers contained strongly coloured water with values up to 80 Unit. Pt. Co. and $\mathrm{pH}$ with a tendency to acidity (5.9-7.0). Their conductivities varied between $24.4 \mu \mathrm{S} \mathrm{cm}^{-1}$ (Notué, Lake Huillinco) and $464.0 \mu \mathrm{S} \mathrm{cm}^{-1}$ (Curahueldo, Lake Cucao). Most inflows showed high concentrations of nitrate (> $200 \mu \mathrm{L}^{-1}$ ), but the total nitrogen lay within the limit of oligotrophy $\left(200-400 \mu \mathrm{L}^{-1}\right)$. Orthophosphate too showed concentrations below the limit of mesotrophy $\left(<15 \mu \mathrm{L}^{-1}\right)$, while the total phosphorus normally registered higher concentrations $\left(16-27 \mu \mathrm{L}^{-1}\right)$. It must be pointed out that the major contribution of nutrients to these lakes came from the rivers with the highest discharge. The outflows showed similar physical and chemical characteristics to those observed for the surface water mass of the corresponding lakes.

\section{Annual load of lakes}

The annual loads of phosphorus and nitrogen in a lake result from the cumulated contributions of all river inflows, plus localized and diffuse sources in the drainage area (equation 1). These sources are summarised in Table 4. Considering the annual load entering through the inflows from the basin of the River Cucao, the contributions can be arranged in a hierarchy. Lakes Tarahuín and Tepuhueico drain into Lake Huillinco, which finally drains to Lake Cucao. It was evident that this is the reason for the high load of nutrients, especially 

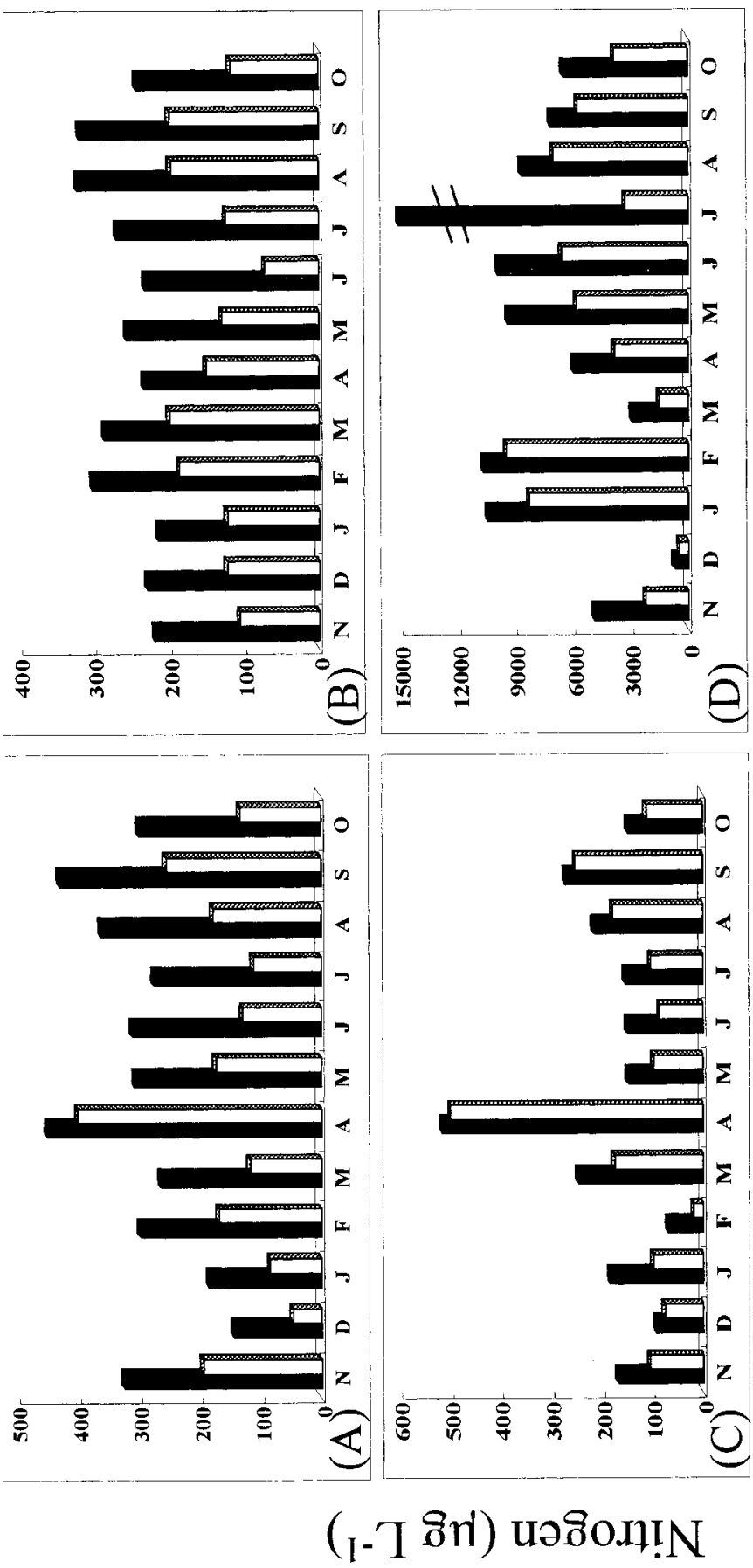

离

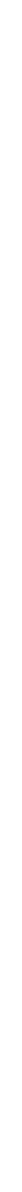

๑

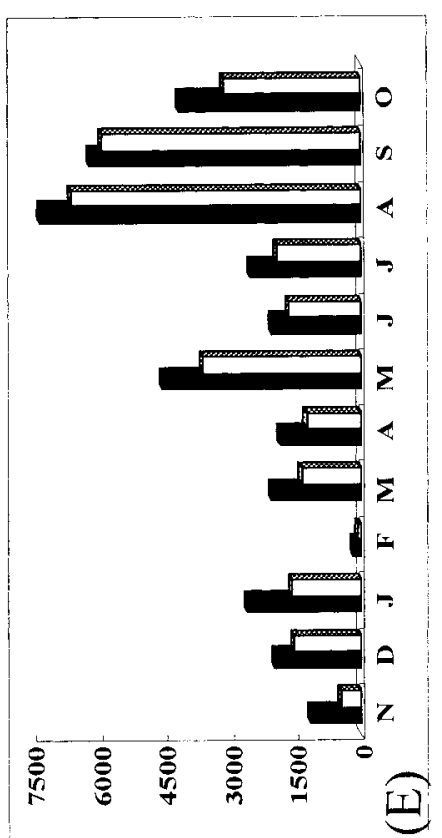

$\frac{\sqrt[0]{0}}{\stackrel{0}{a}}$

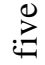

$\Xi \quad$ \%

굴

ఏ

ฮี

00

U

无 胥

当 方

행요

ธี. 를 종ํํ 당 Чै

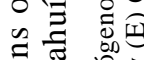

。ี

등

记寻

官

$u \cdot \overline{0}$

$\because$ 盯

运运豞 


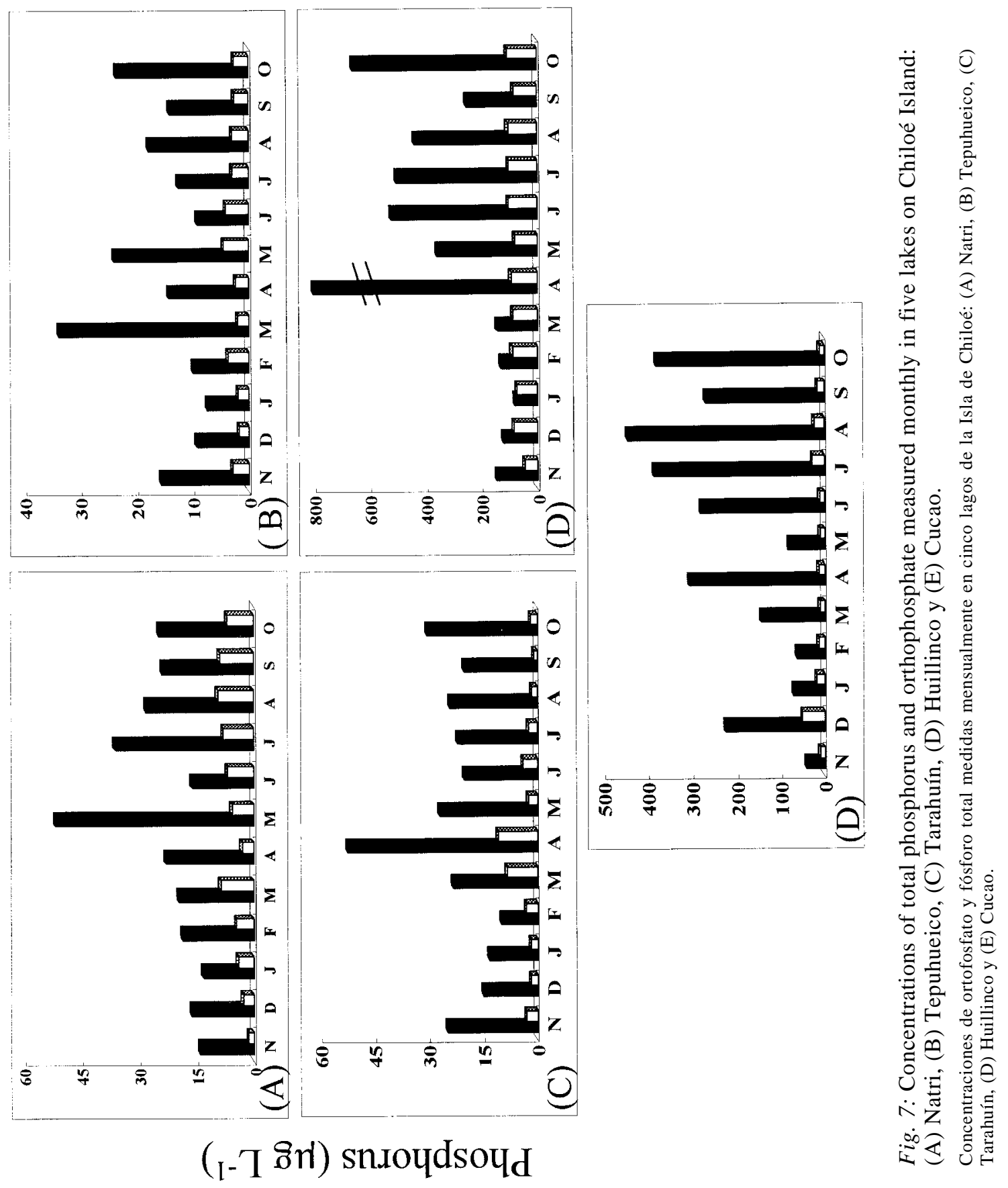


TABLE 4

Load and mass balance of total phosphorus and nitrogen in five lakes of the Chiloé Island

Carga y balance de masa del fósforo y nitrógeno total en cinco lagos de la Isla de Chiloé

\begin{tabular}{|c|c|c|c|c|c|c|}
\hline Load of lake & $L_{T}$ & $L_{D S}$ & $L_{A}$ & $L_{G}$ & $L_{S}$ & $L$ \\
\hline \multicolumn{7}{|c|}{ Phosphorus ( $\left.\mathrm{mg} \mathrm{m}^{-2} \mathrm{y}^{-1}\right)$} \\
\hline Natri & 95 & 38 & 25 & 763 & 0 & 921 \\
\hline Tepuhueico & 948 & 4.7 & 60 & 204 & 0 & 1,216 \\
\hline Tarahuín & 202 & 14 & 52 & 590 & 0 & 858 \\
\hline Huillinco & 1,603 & 34 & 65 & 571 & 1,976 & 4,249 \\
\hline Cucao & 7,617 & 44 & 26 & 217 & 0 & 7,904 \\
\hline \multicolumn{7}{|c|}{ Nitrogen $\left(\mathrm{mg} \mathrm{m}^{-2} \mathrm{y}^{-1}\right)$} \\
\hline Natri & 843 & 346 & 131 & 5,326 & 0 & 6,646 \\
\hline Tepuhueico & 8,455 & 43 & 593 & 1,196 & 766 & 11,053 \\
\hline Tarahuín & 1,442 & 127 & 132 & 3169 & 0 & 4,870 \\
\hline Cucao & 13,906 & 402 & 486 & 1311 & 0 & 16,105 \\
\hline Huillinco & 19,633 & 312 & 181 & 3,780 & 52,696 & 76,602 \\
\hline \multicolumn{7}{|l|}{ Mass balance } \\
\hline Phosphorus (Tons) & $L_{\text {int }}$ & $L_{\text {out }}$ & $L_{\text {ext }}$ & $\pm D T P$ & & \\
\hline Natri & -5.0 & 2.2 & 7.2 & +0.02 & & \\
\hline Tepuhueico & -8.6 & 8.8 & 17.5 & +0.03 & & \\
\hline Tarahuín & -4.9 & 1.7 & 6.6 & +0.01 & & \\
\hline Huillinco & 38 & 80 & 43 & +1.2 & & \\
\hline Cucao & -55 & 28 & 84 & +0.52 & & \\
\hline Nitrogen (Tons) & $L_{i n t}$ & $L_{\text {out }}$ & $L_{e x t}$ & $\pm \mathrm{D} T P$ & & \\
\hline Natri & -32 & 19 & 52 & +0.3 & & \\
\hline Tepuhueico & +11 & 158 & 147 & +0.6 & & \\
\hline Tarahuín & -24 & 13 & 37.5 & +0.13 & & \\
\hline Huillinco & $+1,006$ & 1,447 & 457 & +16.1 & & \\
\hline Cucao & -748 & 735 & 1491 & +7.5 & & \\
\hline
\end{tabular}

phosphorus, entering Lake Cucao (Table 4). In the case of Lake Natri the small contributions of phosphorus and nitrogen were explained by its independence from other river basins and the direct relationship between the size of the drainage area and the surface of the lake (relation $A_{d}: A_{o}$, Table 2). Interpretation of the nitrogen loadings are more difficult, given the complex cycles of this nutrient. The direct and diffuse loads of residual waters were related to the locations of human density and agricultural activities, which were particularly developed in the drainage areas of the lakes Huillinco, Cucao and Natri. Low loadings from all these sources were recorded for lakes Tarahuín and Tepuhueico, which have the lowest population densities in their drainage areas. The contribution of nutrients from rain water was, in general, in direct relationship to the surface area of each lake (Table 2 and 4). The load of nutrients from fish farming centres depended on the number of fish farms in each water body: extreme values were registered in lakes Tepuhueico (lowest) and Natri (highest). Nevertheless, in terms of percentage, the smallest contribution of nutrients from fish farming was found in Lake Cucao $(2.7 \%$ of phosphorus and $8 \%$ of nitrogen), whereas, the highest was measured in Lake Natri with $80 \%$ of both phosphorus and nitrogen derived from fish farming (Table 4).

\section{Mass balance of lakes}

The mass balance establishes the amount of total phosphorus and nitrogen persisting in a 
lake according to the income and egress of these nutrients. Indirectly the mass balance measures the nutrients incorporated from the sediments into the water column, or those that are integrated into the sediments from the water body (internal loading). The mass balance thus becomes a useful tool with which to obtain an estimation of the magnitude of the internal load and/or sedimentation of nutrients (phosphorus and nitrogen), within the water mass. The presence of internal loading occurs when a positive value is obtained in the mass balance equation given by Vollenweider (1976, equation 2), whereas a negative value means that there are processes of nutrient sedimentation. However, for nitrogen, the interpretation of flows is more complex due to the gaseous phase within its cycle so the appearance of negative flows does not necessarily mean sedimentation. For nitrogen it can be due to the balance between nitrification and denitrification.

According to the mass balance (Table 4) for Lake Huillinco, internal loading corresponded to 38 tons of phosphorus and 1,006 tons of nitrogen, which is evident since the mass of nutrients in its outflow was higher than in its inflows. The presence of internal loading in Lake Huillinco was confirmed by the anoxic conditions in most of the water column. In contrast, Lake Tepuhueico registered internal loading of 11 tons of nitrogen (Table 4); but, as was mentioned previously, due to the low oxygen concentration in the bottom of this lake, the internal load would be related to the balance between denitrification and nitrification. In the others lakes, sedimentation of phosphorus and nitrogen was observed.

\section{Biological characterization: Chlorophyll a}

The concentrations of chlorophyll $a$ in the five lakes ranged between $0.56 \mu \mathrm{g} \mathrm{L}^{-1}$ (Huillinco, Julio) and $70.5 \mu \mathrm{g} \mathrm{L}^{-1}$ (Natri, March). In all the lakes the maximum was registered in the period March-April. The lowest levels of chlorophyll $a$ were observed in lakes Huillinco and Cucao (annual average $<3.4 \mu \mathrm{g} \mathrm{L}^{-1}$ ). Lake Tepuhueico had concentrations lower than $13 \mu \mathrm{g} \mathrm{L}^{-1}$, with some lower than $1 \mu \mathrm{g} \mathrm{L}^{-1}$, specially at the end of winter and during spring. The concentrations in Lake Tarahuín hardly varied, with a maximum of $14 \mu \mathrm{g} \mathrm{L}^{-1}$ (April). In contrast, Lake Natri showed two extraordinarily high concentrations during May and April (autumn); but in the remaining period the concentrations observed were below $10 \mu \mathrm{g} \mathrm{L}^{-1}$.

\section{Phytoplankton}

The main characteristics of the phytoplankton community are summarized in Table 5. In all 5 lakes, 87 species were determined most of which were diatoms (Bacillariophyceae, 32 species) or green algae (Chlorophyceae, 33 species). Lakes Tepuhueico, Huillinco and Cucao showed similarities in species richness, abundance and seasonal behavior with maximum biomass and density during summer. These three lakes also presented a remarkable predominance of the species Ankistrodesmus mirabilis (green algae) and Chroomonas sp. (Cryptophyceae). These lakes had low algal densities and biomasses (Fig. 8 and 9), especially Cucao and Huillinco, in spite of their high concentrations of nutrients (Fig. 6 and 7). The opposite situation was observed in lakes Natri and Tarahuín. Lake Natri had its maximum algal biomass and density during spring, Lake Tarahuín during winter (Fig. 8 and 9). In lakes Cucao and Huillinco there was a strong gradient in the vertical distribution of the species, related to the salinity gradient whereas, in the fresh water lakes the vertical distribution of the phytoplankton was more homogenous. In lakes Cucao and Huillinco species of diatoms characteristic of mixohaline environments were recorded. In lakes Tarahuín and Cucao the presence of Ceratium hirundinella, a species apparently introduced to Chilean freshwater systems through fish farming activities, is noteworthy.

\section{Zooplankton}

The most important characteristics of the zooplankton communities are shown in Table 6. In the freshwater lakes, rotifers constituted the predominant group in terms of density, Keratella cochlearis and its varieties $(K$. cochlearis var. teca and K. c. var. tropica and K. c. var. quadrata) being the most important species, followed by Polyarthra vulgaris (Fig. 10). It must be pointed out that Keratella cochlearis varieties were recorded for the first time in South Chilean lakes. In Lake Tarahuín important species such as Trichocerca similis and Chonochilus unicornis were also found among the rotifers. Among the copepods, the cyclopoid Tropocyclops prasinus was of importance, especially during summer. In general, species such as Boeckella gracilipes and Mesocyclops longisetus were present in all the lakes, but at low densities. In Lake Tepuhueico the presence of Diaptomus diabolicus was of importance. Among the cladocerans, the species Bosmina 


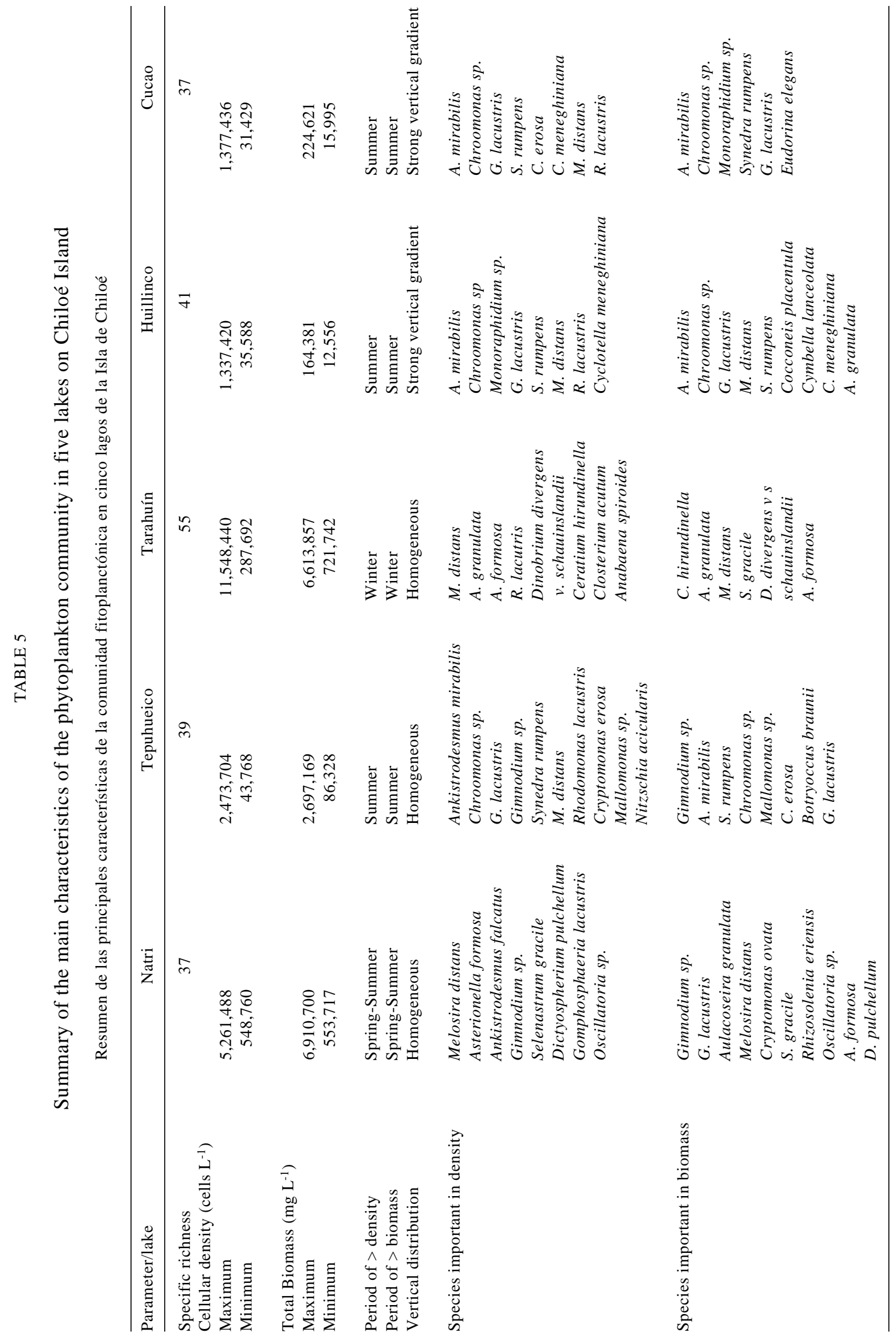




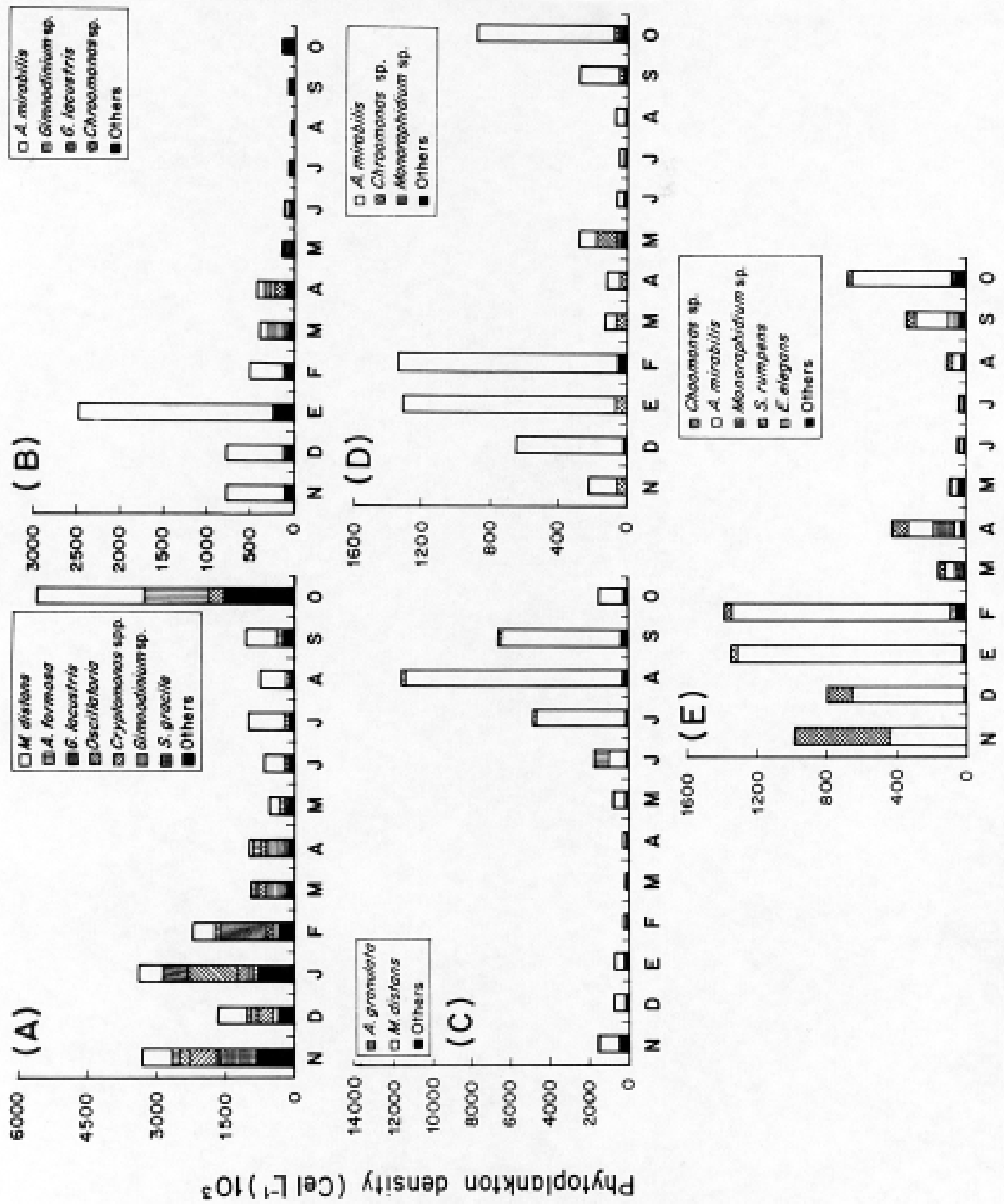

Fig. 8: Phytoplankton density in the five lakes on Chiloé Island: (A) Natri, (B) Tepuhueico, (C) Tarahuín, (D) Huillinco y (E) Cucao.

Densidad del fitoplancton en cinco lagos de la Isla de Chiloé: (A) Natri, (B) Tepuhueico, (C) Tarahuín, (D) Huillinco y (E) Cucao. 


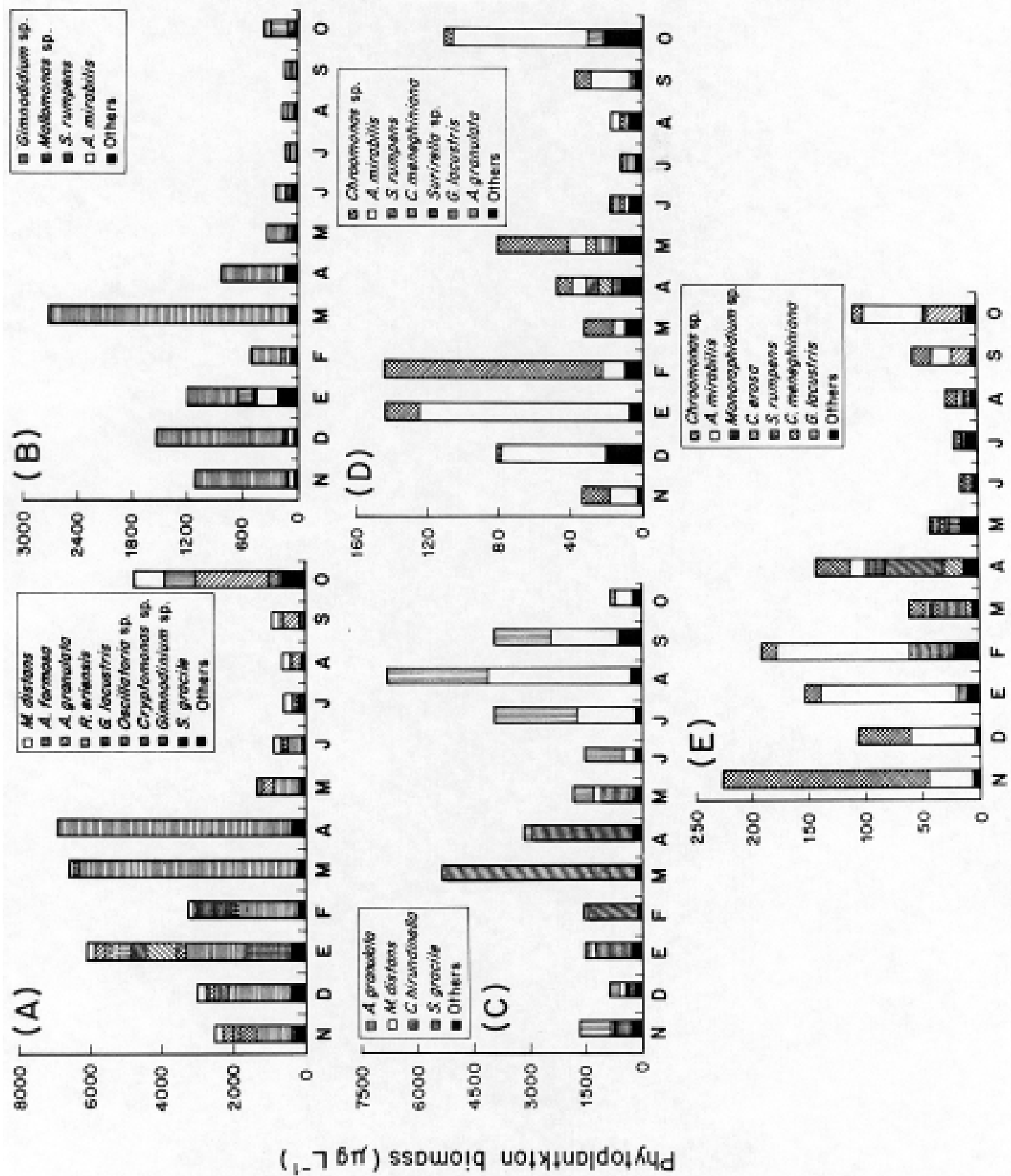

Fig. 9: Phytoplankton biomass in the five lakes on Chiloé Island: (A) Natri, (B) Tepuhueico, (C) Tarahuín, (D) Huillinco y (E) Cucao.

Biomasa del fitoplancton en cinco lagos de la Isla de Chiloé: (A) Natri, (B) Tepuhueico, (C) Tarahuín, (D) Huillinco y (E) Cucao. 
chilensis appeared in all the lakes, reaching its maximal density during February in Lake Natri (Fig. 10). Considering the five lakes, the presence in Lake Tarahuín of Daphnia pulex stands out in spite of its low densities.

In lakes Cucao and Huillinco species were found which represent both the freshwater and marine environments (Fig. 10). Lake Cucao was found to have a high zooplankton density, while in Lake Huillinco density was low, but with greater species richness. In Lake Cucao the Rotifers (Fig. 10) predominated, registering their maximum density in March with $K$. cochlearis, and its varieties, and Hexarthra fennica, the latter also being found during February. A second peak was observed in December with a predominance of Synchaeta sp.. During winter, in general, the zooplankton density declined, but was maintained at a low level by the marine plankton. Of the freshwater species, D. diabolicus should be noted, especially in May, although at low densities.

In Lake Huillinco more freshwater species were found with one peak during March and a second in February and October. During March $K$. cochlearis and its varieties predominated with Filinia longiseta, crustacean larvae and marine plankton. The copepod $D$. diabolicus appeared during the spring and summer, reaching its maximum in March. In both lakes Tropocyclops prasinus and $M$. longisetus were found sporadically, the remaining crustaceans species being recorded at low densities. As in Lake Cucao, during winter the marine plankton prevailed. Three taxa of marine origin were represented in the plankton of Lake Huillinco: larvae and adults of Poliqueta and Appendicularia. Their high densities were found during June, July and August, coincident with a decreasing freshwater plankton. In Lake Cucao, as at L. Huillinco, the same species of adult and larval stages of marine plankton appeared, and occasionally a species of Decapoda. Within the Marine Plankton the Poliqueta larvae appeared in greatest numbers $(90 \%)$.

In their vertical distributions, the freshwater species were concentrated mainly between 10 and $6 \mathrm{~m}$ deep, while the species of marine origin located around $10 \mathrm{~m}$, since the salinity at this depth was higher than at the surface.

\section{DISCUSSION}

Five hydrographic river basins on Chiloé Island were studied for the first time. They contain three freshwater lakes (Natri, Tepuhueico and Tarahuín) and two (Huillinco and Cucao) which are strongly influenced by the sea. The lakes are mostly of recent origin, mainly associated with the last glaciation, but lakes Huillinco and Cucao have also been influenced by tectonic events (present study and Laugenie, 1982). Lakes Tarahuín, Tepuhueico, Huillinco and Cucao belong to the extensive hydrographic system of the River Cucao; whereas the basin of Lake Natri is isolated. Lake Huillinco has the largest catchment area and, based on the relationship of $A_{d}: A_{o}$ (Table 2), is the basin most susceptible to anthropogenic influences (deforestation, agriculture etc). Similar situations have been discussed with regard to the large lakes located in South Chilean Patagonia (Soto \& Campos 1996).

Their physical, chemical and biological characteristics suggest several differences among these lakes and based on their thermal profiles we differentiated: (1) Lake Natri as a typical monomictic temperate lake; (2) Lake Tarahuín which does not develop a complete thermocline during summer; (3) Lake Tepuhueico which occupies an intermediate position and, (4) lakes Huillinco and Cucao which both have an inverted stratification, with three differentiated water masses as a result of the marine influence, and can therefore be described as meromictic lakes influenced by the external supply of salt (Wetzel 1983). The strong fluctuations in the depth of the thermocline $(5-25 \mathrm{~m})$ in Lake Natri and the absence of a thermocline in Lake Tarahuín are explained by the shallow depth of the latter and the strong winds in this area, which prevent stable stratification. The winds are, however, not strong enough to destroy the marked chemoclines in lakes Huillinco and Cucao. In addition, all these lakes can be classified as dystrophic due to their brown coloured waters, which can be explained by the input of allochthonous organic matter with a high content of humic substances. The brown colouration is associated with remarkably low transparencies which prevent higher chlorophyll concentrations in all the lakes.

In all five lakes total phosphorus concentrations were high compared to those of orthophosphate (Fig. 7). Brown waters rich in organic matter have been known to exhibit higher total phosphorus concentrations when they are compared with clear water lakes (Hutchinson 1957, Wetzel 1983, Jones 1992). There is empirical evidence relating the strong association of phosphate and iron with dissolved material of high molecular weight in waters rich in humic substances (Shaw et al. 2000). The ionic composition and $\mathrm{pH}$ of such 


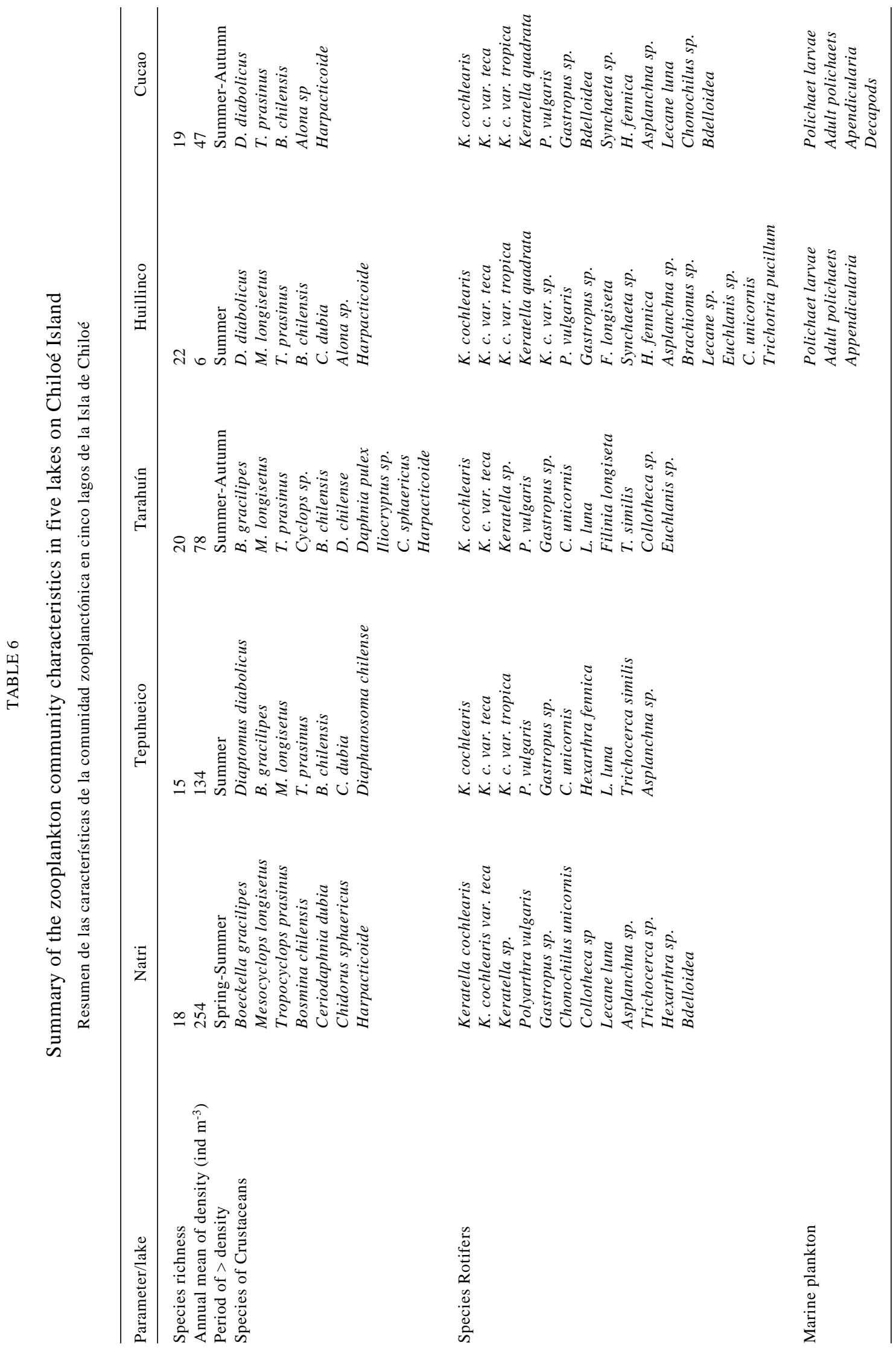




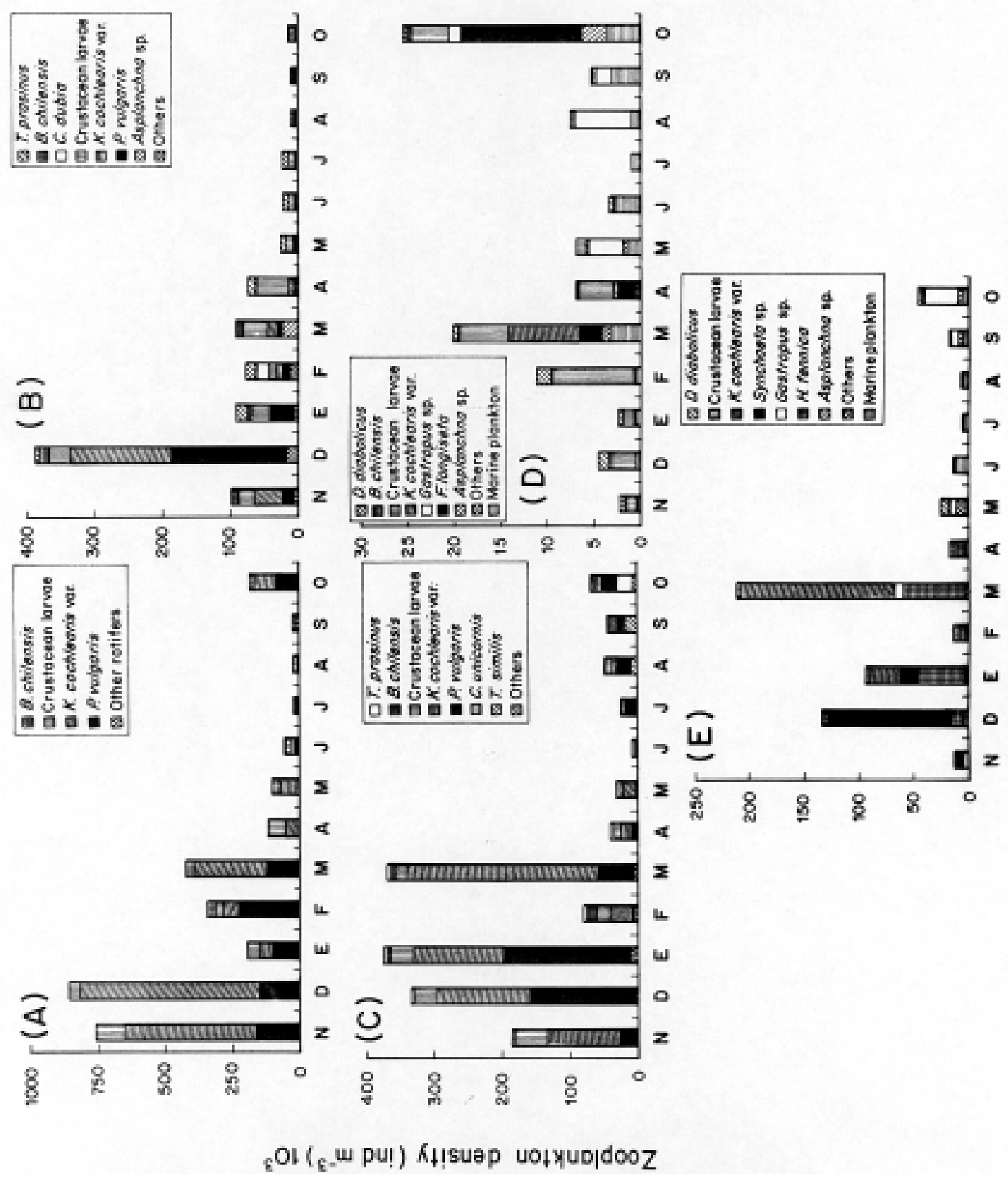

Fig. 10: Zooplankton density in the five lakes on Chiloé Island: (A) Natri, (B) Tepuhueico, (C) Tarahuín, (D) Huillinco y (E) Cucao.

Densidad del zooplankton en cinco lagos de la Isla de Chiloé: (A) Natri, (B) Tepuhueico, (C) Tarahuín, (D) Huillinco y (E) Cucao. 
waters also influence the speciation of iron and phosphate (Shaw et al. 1996), making the chemical reactions more complex than those postulated for clear lakes. Thus, under certain conditions, humic substances can decrease the phosphate available to algae and in that way we could, in part, explain the low orthophosphate concentrations found in the lakes studied here.

In lakes Cucao and Huillinco the organic matter from both internal and external sources settles towards the bottom, having originated by decomposition in anoxic conditions. Due to their very strong chemoclines, the passage of oxygen to the bottom of these lakes is very improbable, and the consequences of this are unpredictable because in Lake Huillinco a strong odour of sulphuric acid was detected when we extracted samples from the deep zones.

In lakes Huillinco and Cucao phytoplankton biomass and zooplankton density were very low which could be explained, on the one hand, by the anoxic environment from 7-10 $\mathrm{m}$ down to the bottom of these lakes, making only a thin layer of water available for productive processes, and on the other, by the constant marine influence on these lakes which prevents the establishment of a plankton community under conditions of variable salinity. Nevertheless, the highest diversity of species was found in the plankton community of Lake Huillinco. In the zooplankton communities of all the lakes the richness of rotifer and copepod species stands out, but most of these species appeared sporadically and in low densities. In their vertical distribution, the species are, to a large extent, distributed between 3 and $10 \mathrm{~m}$, with the rotifers and cladocerans predominating in the superficial water. The small sizes of the organisms in the zooplankton communities of these lakes also deserve attention and could indicate a displacement of the trophic chain as proposed by Brooks \& Dodson (1965). Another interesting point is the presence of several varieties of the rotifer $K$. cochlearis, which appear to be associated with the strong winds and turbulence (Schmidt-Araya, personal communication). The presence of $D$. pulex (Tarahuín) in the zooplankton community is also worthy of remark due to the scarcity of Daphnia species recorded at this latitude, in both large and deep North Patagonian lakes and lakes of moderate depth $(>50 \mathrm{~m})$, the factors determining its presence being unknown. Also remarkable is the extension in its distribution to the South of Diaptomus diabolicus (= Tumeodiaptomus d.).

With regard to the nutrients, the freshwater lakes showed an annual average of around 300 $\mu \mathrm{g} \mathrm{L}^{-1}$ total nitrogen (Fig. 6), whereas in lakes Cucao and Huillinco, the annual mean exceeded 3,000 $\mu \mathrm{g} \mathrm{L}^{-1}$. Hedin \& Campos (1991) found low nutrient concentrations in Chiloé stream waters suggesting highly weathered, nutrient poor soils. Oyarzún et al. (1997) investigated the watershed of Lake Huillinco and found that the contributions of total nitrogen and phosphorus in the streams, especially nitrogen in organic form, were exported mainly from native forests. In the large Lake Rupanco (Chilean North Patagonia) Oyarzún (2000) found nutrients to be near to the level of mesotrophy, with high nitrogen inflow through the streams, due principally to changes in land use (deforestation, agriculture), which accelerate the eutrophication process. Similar changes in the land use of river basins on Chiloé Island could have immeasurable consequences, because the natural contribution of organic humic substances from the forest maintains an equilibrium among the physicochemical and biological compounds. At the time of our investigation, a high percentage (70-80 $\%$ ) of mature native and regenerating forest still covers these hydrographic basins on Chiloé.

Phosphorus concentration has long been related to the trophic status of a lake, especially as indicated by chlorophyll concentration (Vollenweider 1969, Dillon \& Rigler 1974, Carlson 1977, Schindler 1978, among others). Both phosphorus and nitrogen have been put forward as limiting factors for phytoplankton growth (Schindler 1978, Burns 1991, Soto \& Campos 1995, among others). Nutrient input to a lake depends on external contributions from its drainage basin through rain water and land use (agriculture, forestry, urban, industrial etc.) and, according to Ryding \& Rast (1992), mass balances are the only reliable method for clarifying the origins of various nutrients with respect to the nutrient flow dynamics, between the sediments and the water mass. Eutrophication models have been used only recently in South Chile (Campos et al. 2001), due to the fact that in recent decades a large number of lakes, including those on Chiloé Island, have been used for fish farming activities such as smolt growth centres. It is assumed that these activities result in unnatural additional inputs of nutrients to the lakes. With the aim of controlling the actual loads of the lakes, and their mass balances, we applied the models of Ryding \& Rast (1992) and Vollenweider (1976). As shown in the results, Lake Natri demonstrated the major impact of fish farming activities and this situation has become serious, since the renewal time of the water in Lake Natri, the largest of all the lakes in this study, is in the order of 3.5 years $(\mathrm{H}$. 
Campos et al. unpublished results, calculated after Larsen \& Mercier 1976).

The actual nutrient loads and mass balances of lakes Huillinco and Cucao constitute quite a complex system in relation to the dynamics of their water masses, due to the strong marine influence, especially during periods of high tides (Fig. 11). The two lakes are joined by the Caldera Channel, are of different depths and also have water columns of different salinities and chemoclines of different strengths, and therefore different nutrient cycles. The impossibility of complete circulation in these water bodies allows an accumulation of phosphorus and nitrogen, among other compounds, making even more complex the calculation of actual loads and critical loads of these lakes.

To explain the high salinity found at the bottom of Lake Huillinco we hypothesize that during the 1960's earthquake, a large wave could have brought a considerable mass of salt water into this system. Because Lake Huillinco is deeper than both its outflow channel and Lake Cucao, part of this salt water was retained within the lake without possibility of circulation and evacuation. In addition, salt is probably carried into the lake through atmospheric transport.

Chile is characterised by its long latitudinal extent and diverse geography, encompassing a variety of lake systems, all of them different from the Chiloé lakes. In northern Chile, high mountain lakes (Altiplano) dominate (Dorador et al. 2003), plus small saline ponds. Numerous mesotrophic or eutrophic reservoirs characterise the freshwater bodies of central Chile, the largest being Lake Rapel (Vila et al.
2000). In this region there are also some deep oligotrophic, high Andean lakes (Geller 1992, Tartarottii et al. 1999). In the northern part $\left(37^{\circ} 55^{\prime} \mathrm{S}, 73^{\circ} 18^{\prime} \mathrm{W}\right)$ of the southern lake district are the lakes which ${ }^{1}$ Parra et al (2001) called Nahuelbutanos, characterized by and their coastal or mountain influence and differences in their trophic status. The lakes of Chiloe Island differ from all of these lake systems, principally because of their different water chemistry, origins, hydrological regimes, and the influence of their catchment areas.

\section{CONCLUSIONS}

Within southern Chile, the Chiloé lakes can be compared to those of north Patagonia $\left(38-26^{\circ}\right.$ S, 71-19 $\mathrm{W}$, Thomasson 1963) both systems having glacial origins and the latter being strongly influenced by volcanic activity (Campos 1984). However, in terms of their morphometric characteristics, the Chiloé lakes are shallower and much smaller than those of north Patagonia. Their temperature regimes vary through warm-monomictic to polymictic or meromictic, whereas the north Patagonian lakes are all warm monomictic (Campos 1984, Soto 2002). A unique feature of the Chiloé lakes is the presence of humic substances which presumably limits their productivity through high light attenuation and the reduced availability of nutrients, due to the formation of complexes with phosphorus. Finally, concerning the phyto- and zoo-plankton communities, the North Patagonian lakes show lower species diversity with a dominance of diatoms and calanoid species in comparison to

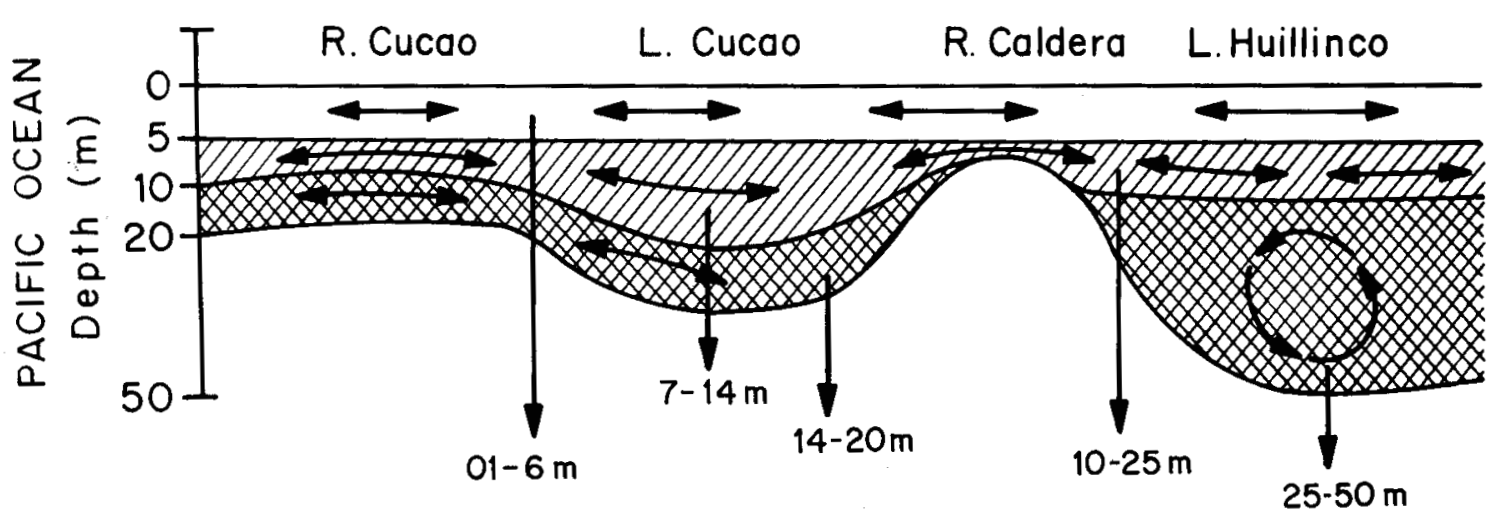

Fig. 11: Model proposed for the dynamic processes of the water in the Lake Huillinco-Cucao system.

Modelo propuesto para los procesos de la dinámica del agua en el sistema de los lagos Cucao-Huillinco. 
the humic Chiloé lakes (Soto \& Zuñiga 1991, Villalobos 1994, this study).

To conclude, this investigation is one of the first multidisciplinary studies looking at the drainage basin inflows, land uses and characteristics of the catchment areas, influencing the limnological characteristics, nutrient loadings and mass balances of these five lakes on Chiloé Island. The results constitute a basis for future studies aimed at evaluating anthropogenic influences and their consequences for the streams and lacustrine systems of the Island.

\section{ACKNOWLEDGEMENTS}

This study was financed by a Grant from the Fondo de Investigación Pesquera, Project FIP 96-54 and a grant from the Universidad Austral de Chile. The investigation was initiated by the senior author Hugo Campos, who died in 1998 during a field trip. We dedicate this work to his memory in recognition of his worthy limnological work in Chile. The authors thank Dr. M. Burgis for helpful comments on the manuscript and correction of the English. We also thank and appreciate the comments of two anonymous reviewers. L. Villalobos gives special thanks to César Cuevas for his helpful comments and assistance. We acknowledge the technical assistance of Gloria Agüero, Raúl Arriagada and Rosa Cárcamo.

\section{LITERATURE CITED}

AMBÜHL H \& M SCHMIDT (1965) Die Bestimmung geringster Mengen von Phosphation im Wasser von Binnenseen. Schweizer Zeitschift Hydrologie 27: 172-192.

BROOKS JL \& SI DODSON (1965) Predation, body size and composition of plankton. Science 150: 28-35.

BRANDES M, NA CHOWDHRY \& WW CHENG (1974) Experimental study on removal of pollutants from domestic sewage by underdrained soil filters, National Sewage Disposal Symposium. American Society Agriculture Engineers (USA) 3: 29_36.

BRUNETT P (1963) Les cartes des pentes. Revue Géographique des Pyrénées et du Sud-Ouest 23: 317-334.

BRÜGGEN JM (1950) Fundamentos de la geología de Chile. Instituto Geográfico Militar, Santiago, Chile. 374 pp.

BURNS CW (1991) New Zealand lakes research. New Zealand Journal of Marine Freshwater Research 25: $359-379$

CAMPOS H (1984) Limnological studies of Araucanian lakes Chile. Verhandlungen Internationale Vereinigung Limnologie 22: 1319- 1327

CAMPOS H, J ARENAS, C JARA, T GONSER \& R PRINS (1984) Macrozoobentos y fauna íctica de las aguas limnéticas de Chiloé y Aysen continentales Chile. Medio Ambiente (Chile) 7: 52-64
CAMPOS H, J F GAVILÁN, V MURILlO \& P ALARCÓN (1996) Presencia de Cheirodon australe (Pisces: Characidae) en el lago Tarahuín (Isla Grande de Chiloé, $42^{\circ} 40^{\prime} \mathrm{S}$, Chile) y su significado zoogeográfico. Medio Ambiente (Chile) 13: 69-79.

CAMPOS H, DP HAMILTON, L VILLALOBOS, J IMBERGER \& A JAVAM (2001) A modelling assessment of potential for eutrophication of Lake Riñihue, Chile. Archiv für Hydrobiologie 151: 101-125.

CARLSON RE (1977) A trophic state index for lakes. Limnology and Oceanography 23: 361-369.

DI CASTRI F (1968) Esquisse écologique du Chili: In: Deboutteville D \& C Rapoport (eds) Biologie de L'Amérique Australe: 7-52. Editions du Centre National de la Researche Scientific, París, France.

DILLON PJ \& FH RIGLER (1974) The phosphoruschlorophyll relationship in lakes. Limnology and Oceanography 19: 767-773.

DORADOR C, PARDO R \& I VILA (2003) Variaciones temporales de parámetros físicos, químicos y biológicos de un lago de altura: el caso del lago Chungará. Revista Chilena de Historia Natural 76: 15-22.

EATON AD, LS CLESCERI \& AE GREENBERG (eds) (1995) Standard methods for the examination of water and wastewater. Nineteenth edition. American Public Health Association, United Book Press, Baltimore, Maryland, USA. xv $+1,541$ pp.

GELLER W (1992) The temperature stratification and related characteristics of Chilean lakes in midsummer. Aquatic Science 54: 37-57.

HANEY JF \& DH HALL (1973) Sugar-coated Daphnia: a preservation technique for Cladocera. Limnology and Oceanography 18: 331-332.

HEDIN LO \& H CAMPOS (1991) Importance of small streams in understanding and comparing watershed ecosystem processes. Revista Chilena Historia Natural 64: 583-596.

HOFFMANN A (ed) (1999) El bosque chilote. Defensores del bosque chileno: historia natural del Archipiélago de Chiloé. Conservación y desarrollo sustentable de sus bosques y biodiversidad. Colección Bosqueduca, GraficAndes, Santiago, Chile. 108 pp.

HUTCHINSON GE (1957) A treatise on limnology, I. John Wiley \& Sons, New York, New York, USA, 1115 pp.

JONES RI (1992) Phosphorus transformations in the epilimnia of small humic forest lakes. Hydrobiologia 243/244: 105-111.

LARSEN DP \& HT MERCIER (1976) Phosphorus retention capacity of lake. Journal Fisheries Research Board Canada 33: 1742-1750.

LAUGENIE C (1982) La region des lacs, Chili meridional. rechérches sur l'évolution géomorphologique d'un piémont glaciaire quaternaire andin. These de Doctorat d' Etat presentee devant L'universite de Bordeaux, France III. 822 pp.

OYARZÚN CE (2000) Water quality and soil use changes in the lakes of southern Chile. In: Raynal JA, JR Nucknois, R Reyes \& M Ward (eds) Environmental engineering and health sciences: 379-385. Resources Publications, Boulder, Colorado, USA.

OYARZÚN CE, H CAMPOS \& A HUBER (1997) Exportación de nutrientes en microcuencas con distintos uso del suelo en el sur de Chile (Lago Rupanco, X Región). Revista Chilena Historia Natural 70: 507-519.

RYDING SO \& W RAST (1992) El control de la eutroficación en lagos y pantanos. Editorial Pirámide S.A., UNESCO, Madrid, Spain. 375 pp.

RODRÍGUEZ S (1993) Determinación cuantitativa de la carga de desechos ingresados al lago Ranco por 
efecto del cultivo de especies salmónidos. Tesis de Biología Marina, Facultad de Ciencias, Universidad Austral de Chile, Valdivia, Chile. 147 pp.

SCHINDLER DW (1978) Factor regulating phytoplankton production and standing crop in the world's freshwaters. Limnology Oceanography 23: 478-486.

SCOR-UNESCO (1969) Determination of photosynthetic pigments in sea water. Second edition. UNESCO, Imprimerie Rolland, Paris, France. 69 pp.

SHAW PJ, RI JONES, H De HAAN (1996) Contrasting experimental manipulation of the acidity of catchment drainage water: effects on interactions between humic substances, iron and phosphate. Environment International 22: 611-618.

SHAW PJ, RI JONES, H De HAAN (2000) The influence of humic substances on the molecular weight distributions of phosphate and iron in epilimnetic lake waters. Freshwater Biology 45: 383-393.

SOTO D (2002) Oligotrophic patterns in southern lakes: the relevance of nutrients and mixing depth. Revista Chilena Historia Natural 75: 377-393.

SOTO D \& H CAMPOS (1996) Los lagos oligotróficos del bosque templado húmedo del sur de Chile. In: Armesto JJ, C Villagran \& K Arroyo (eds) Ecología de los bosques nativos de Chile: 317-333. Editorial Universitaria, Santiago, Chile.

TARTAROTTI B, S CABRERA, R PSENNER \& R SOMMARUGA (1999) Survivorship of Cyclops abyssorum tatricus (Cyclopoida, Copepoda) and Boeckella gracilipes (Calanoida, Copepoda) under ambient levels of solar UVB radiation in two highmountain lakes. Journal of Plankton Research 21: 549-560.

STRAHLER AN (1981) Geografía física. Quinta edición. Impresiones Omega, Barcelona, Spain. 767 p.

SUBIABRE A \& ROJAS C (1994) Geografía física de la Región de Los Lagos. Ediciones Universidad Austral de Chile, Valdivia, Chile. 118 pp.

UTERMÖHL H (1958) Zur Vervollkommung de quantitativen Phytoplankton-Methodik. Mitteilung International Vereinigung Limnologie 9: 1-38.

VILA I, M CONTRERAS, V MONTECINO, J PIZARRO \& DD ADAMS (2000) Rapel: a 30 years temperate reservoir. Eutrophication or contamination? Archiv für Hydrobiologie 55: 31-44.

VILLALOBOS L (1994) Zooplankton of Andean temperature lakes in South-America with special emphasis on the Daphnia species: taxonomy, geographical distribution, ecology, and functional morphology of the filtering apparatus.Dissertation University of Konstanz, Konstanz, Germany. 197 pp.

VOLLENWEIDER RA (1976) Advances in defining critical loading levels for phosphorus in lake eutrophication. Memories Istituto Italiano Idrobiologie 33: 53-83.

WETZEL RG (1983) Limnology. Second edition. Saunders College Publishing, Philadelphia, Pennsylvania, USA. 760 pp. 